\title{
Article \\ Quantification of Groundwater Discharge in a Subalpine Stream Using Radon-222
}

\author{
Elizabeth Avery ${ }^{1, \dagger}{ }^{\dagger}$ Richard Bibby ${ }^{2}$, Ate Visser ${ }^{2}$, Bradley Esser ${ }^{2}$ and Jean Moran ${ }^{1, *}$ \\ 1 Department of Earth and Environmental Sciences, California State University East Bay, Hayward, CA 94542, \\ USA; e.avery@uky.edu \\ 2 Lawrence Livermore National Laboratory, 7000 East Ave, Livermore, CA 94550, USA; bibby1@llnl.gov (R.B.); \\ visser3@llnl.gov (A.V.); esser1@llnl.gov (B.E.) \\ * Correspondence: jean.moran@csueastbay.edu; Tel.: +1-510-885-2491 \\ + Current affiliation: Department of Earth and Environmental Sciences, University of Kentucky, Lexington, \\ KY 40506, USA
}

Received: 4 November 2017; Accepted: 22 January 2018; Published: 25 January 2018

\begin{abstract}
During the dry months of the water year in Mediterranean climates, groundwater influx is essential to perennial streams for sustaining ecosystem health and regulating water temperature. Predicted earlier peak flow due to climate change may result in decreased baseflow and the transformation of perennial streams to intermittent streams. In this study, naturally occurring radon-222 ( $\left.{ }^{222} \mathrm{Rn}\right)$ was used as a tracer of groundwater influx to Martis Creek, a subalpine stream near Lake Tahoe, CA. Groundwater ${ }^{222} \mathrm{Rn}$ is estimated based on measurements of ${ }^{222} \mathrm{Rn}$ activity in nearby deep wells and springs. To determine the degassing constant (needed for quantification of water and gas flux), an extrinsic tracer, xenon (Xe), was introduced to the stream and monitored at eight downstream locations. The degassing constant for ${ }^{222} \mathrm{Rn}$ is based on the degassing constant for Xe, and was determined to be 1.9-9.0 m/day. Applying a simple model in which stream ${ }^{222} \mathrm{Rn}$ activity is a balance between the main ${ }^{222} \mathrm{Rn}$ source (groundwater) and sink (volatilization), the influx in reaches of the upstream portion of Martis Creek was calculated to be $<1$ to $15 \mathrm{~m}^{3} /$ day $/ \mathrm{m}$, which cumulatively constitutes a significant portion of the stream discharge. Experiments constraining ${ }^{222} \mathrm{Rn}$ emanation from hyporheic zone sediments suggest that this should be considered a maximum rate of influx. Groundwater influx is typically difficult to identify and quantify, and the method employed here is useful for identifying locations for focused stream flow measurements, for formulating a water budget, and for quantifying streamwater-groundwater interaction.
\end{abstract}

Keywords: tracer; radioactive isotopes; groundwater influx

\section{Introduction}

Headwater basins are recognized as being critically important for generating runoff that is captured in reservoirs and used for irrigation and municipal water supplies. As climate change progresses, precipitation in subalpine regions will occur more frequently as rain rather than snow, which could have drastic impacts on stream flow and on groundwater recharge. Snowpack in the Sierra Nevada of California allows for slow melting and gradual groundwater recharge in basins; however, as more precipitation occurs as rain, more limited opportunity for groundwater recharge is likely to cause increased run-off as overland flow [1-5]. Groundwater is essential to the area as it provides baseflow to Martis Creek during the dry summer months, which is critically important for maintaining stream ecosystem health. Discharge that ends earlier in the summer or fall as a result of climate change or of groundwater pumping that continues into the summer and fall will put stress on the baseflow of the stream. Groundwater discharge to the stream also moderates stream temperature, especially in the late summer and fall, which is essential to the viability of the fish population in the stream [6-10]. 
Groundwater influx to streams is difficult to quantify, but changes in groundwater influx due to pumping will be regulated in California under the Sustainable Groundwater Management Act [11]. Lower order streams like Martis Creek are typically not gauged and gaining and losing reaches are not known. Geochemical methods like the one described here offer an alternative to physical measurements like stream gauging and to modeling methods that may be associated with high uncertainty.

A number of studies have used ${ }^{222} \mathrm{Rn}$ as a tracer of groundwater influx in streams and a few of those used introduced tracers to determine the degassing constant in order to quantify groundwater influx to the river [12-32]. Most current studies utilizing ${ }^{222} \mathrm{Rn}$ as a tracer use complementary methods to examine groundwater source, age of groundwater, or flowpath. Some studies use physical parameters such as flow measurements [12-16], temperature $[14,15,17,18]$, or electrical conductivity $[14,17-19]$ in addition to ${ }^{222} \mathrm{Rn}$ to better constrain locations of groundwater inflow. Another method is to use multiple naturally occurring tracers, such as major ions [20], ${ }^{4} \mathrm{He}[20,21],{ }^{87} \mathrm{Sr} /{ }^{86} \mathrm{Sr}[15,20,22], \mathrm{Cl}[14,20,23,24]$, and thoron [25], among others, to increase accuracy in groundwater inflow calculations. There have been few studies that use introduced tracers as a way to better characterize the system, though $\mathrm{NaCl}$, propane [26], and $\mathrm{SF}_{6}[16,18,27,30]$ have been used successfully. Multitechnique approaches give a more complete picture of the interaction between groundwater and surface water [24] and lower prediction error for groundwater inflow [16]. For instance, resolutions of groundwater inflow rates can be as low as $5 \mathrm{~mm}$ /day for electrical conductivity and ion tracers and $2 \mathrm{~mm} /$ day for radon [28].

In this study, we identified reaches of Martis Creek with groundwater discharge by measuring the concentration of naturally occurring ${ }^{222} \mathrm{Rn}$ and introduced xenon (Xe). Radon-222 is a radioactive (half-life 3.8 days) gaseous daughter product in the ${ }^{238} \mathrm{U}$ decay series that accumulates in groundwater. Cox et al. [33] also used ${ }^{222} \mathrm{Rn}$ as a tracer of groundwater influx in Squaw Creek in the nearby Olympic Valley. However, in that study, the degassing constant had to be estimated based on prior studies in similar streams. The introduction of a Xe tracer in this study allows direct quantification of the degassing parameter. Additional studies, such as those performed by Clark et al. [34] and Benson et al. [35], have used introduced tracers such as ${ }^{3} \mathrm{He}$ and $\mathrm{SF}_{6}$ to examine gas exchange rates. In this study, groundwater influx is determined by two independent methods: geochemically (using ${ }^{222} \mathrm{Rn}$ as a tracer) and physically (using measured stream discharge). The goals of the study are to compare these methods, and to quantify groundwater discharge in an area where climate change is likely to affect both groundwater recharge and runoff.

\section{Materials and Methods}

\subsection{Study Area}

Martis Valley is located in the Sierra Nevada, north of Lake Tahoe, California (Figure 1). The Martis Valley Basin covers $148 \mathrm{~km}^{2}$, and is at an elevation between 1737 and $1798 \mathrm{~m}$ above mean sea level [36]. In the lower elevations of the Martis Valley groundwater basin, the average annual precipitation is $58.4 \mathrm{~cm}$ /year, while in the headwaters (elevation $2227 \mathrm{~m}$ ), it is $101.6 \mathrm{~cm} /$ year. Approximately $77 \%$ of annual precipitation in the study region occurs as snow. Streams that run through Martis Valley that are tributaries to the Truckee River include Donner Creek, Prosser Creek, and Martis Creek, and surface water is primarily stored in Donner Lake, Martis Creek Lake (downstream of the study area), and Prosser Creek Reservoir.

Average annual stream discharge in Martis Creek is approximately $0.76 \mathrm{~m}^{3} / \mathrm{s}$, with the highest discharge occurring in the spring, and the lowest occurring in the late summer and fall. A water balance performed by Interflow Hydrology in 2003 [37] showed that streamflow losses in October 2002 across Martis Valley were approximately $0.018 \mathrm{~m}^{3} / \mathrm{s}$, while losses at Martis Creek Lake were approximately $0.044 \mathrm{~m}^{3} / \mathrm{s}$, which implies that streams are losing to the groundwater basin over much of the valley [1].

Martis Creek exhibits riffle and pool morphology, has meanders (sinusosity 1.1 to 1.4 ) and vegetation growing along its banks, and springs in the vicinity of the creek support an extensive 
wetland environment. There are also incisions and bank failures seen along reaches of the creek, often where meanders and semideep pools are located [38]. No visible tributaries are located over the study reach, so any increases in discharge can be attributed to groundwater influx.

The stream has been diverted and straightened, mainly downstream of the study reach, during construction of roads and other development, and because this is an area of former logging and cattle grazing. There were at least four diversions associated with cattle grazing in the early to mid-twentieth century found between the top of the study reach and Highway 267, and still-modified channels, such as a double box culvert under Highway 267 (Figure 1) [38].

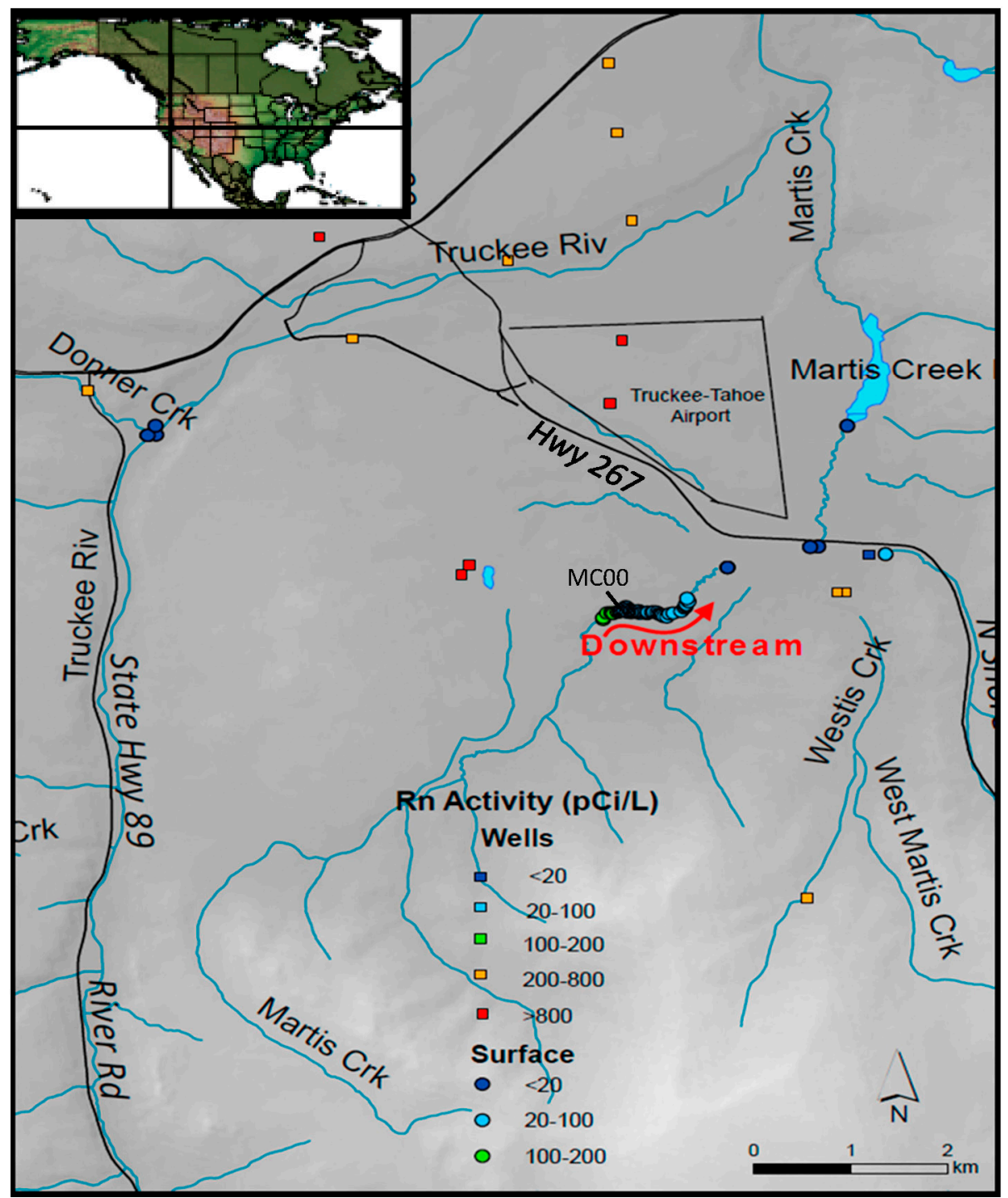

Figure 1. Location map showing results of a distributed survey of ${ }^{222} \mathrm{Rn}$ in wells and streams. The closely spaced samples are the focus of the tracer experiment, where tracer was introduced at location MCO0 and where groundwater influx to Martis Creek is quantified.

\subsection{Radon-222 in Groundwater}

Water samples for ${ }^{222} \mathrm{Rn}$ analysis were collected in the field with minimal exposure to the atmosphere. At groundwater wells, $250 \mathrm{~mL}$ glass bottles were filled with no headspace using tubing connected to a discharge port, and then stored at $4{ }^{\circ} \mathrm{C}$. These samples were analyzed for dissolved ${ }^{222} \mathrm{Rn}$ on a RAD7 Radon Detector (Durridge Company Inc., Billerica, MA, USA) equipped with a RAD $\mathrm{H}_{2} \mathrm{O}$ accessory (Durridge Company Inc.) within two days of being collected and were decay corrected 
to the collection date/time based on the half-life of ${ }^{222} \mathrm{Rn}$. To measure the ${ }^{222} \mathrm{Rn}$ activity in the samples, each sample was aerated for five minutes with the $\mathrm{RAD} \mathrm{H}_{2} \mathrm{O}$ accessory, which forms a closed loop with the RAD 7 Radon Detector. After aeration, there is a five minute period for the ${ }^{218}$ Po to equilibrate followed by four counting periods of five minutes each. The typical detection limit is $20 \mathrm{pCi} / \mathrm{L}$ and the typical standard deviation for four counting periods is $10 \%$.

\subsection{Radon-222 in Surface Water}

For stream water samples, $20 \mathrm{~mL}$ glass vials were prefilled with $10 \mathrm{~mL}$ of scintillation cocktail (mineral oil). A hooked syringe was used to collect $10 \mathrm{~mL}$ of water from approximately $10 \mathrm{~cm}$ beneath the stream surface, and the stream water was injected beneath the cocktail so that the water did not contact the atmosphere during transfer from the syringe to the vial. Glass vials with Teflon-lined caps were used and samples were stored at $4{ }^{\circ} \mathrm{C}$ to minimize volatilization from the vial. Radon-222 is more soluble in organic solvents than in water, so it transfers from the water to the cocktail. This sampling procedure aides in the analysis of ${ }^{222} \mathrm{Rn}$ because certain water-soluble radionuclides such as radium-226 $\left({ }^{226} \mathrm{Ra}\right)$ interfere with ${ }^{222} \mathrm{Rn}$ counting. Samples, standards, and blanks were all analyzed in the same geometry of $10 \mathrm{~mL}$ water underneath $10 \mathrm{~mL}$ mineral oil scintillator cocktail. The $10 \mathrm{~mL}$ collection technique allowed for the collection of a large number of samples in a short period of time, without the need for large containers or other equipment in the field.

After the samples were allowed to equilibrate for at least four hours, they were analyzed on a Quantulus liquid scintillation counter (LSC) for 60 to $90 \mathrm{~min}$. Samples with low ${ }^{222} \mathrm{Rn}$ activity were run twice to compare activity levels between the two runs.

To determine the background count rate for the method, blanks were prepared with deionized water. Background count rates were found to be approximately 0.1 counts per minute (CPM), and this background is subtracted from the CPM activity of each sample. Two laboratory control samples $\left(0.5 \mathrm{~mL}\right.$ of laboratory standard ${ }^{226} \mathrm{Ra}$ liquid with $9.5 \mathrm{~mL}$ water and $10 \mathrm{~mL}$ of mineral oil) were analyzed during each run for instrument calibration. The raw data (in CPM) was then converted into ${ }^{222} \mathrm{Rn}$ activities using the equation

$$
\text { Activity }=\left(\frac{\mathrm{CPM}_{\text {sample }}-\mathrm{CPM}_{\text {background }}}{2.22 \times e \times V}\right)
$$

where $e$ is the Efficiency (CPM on an instrument divided by the known DPM (DPM being Decays Per Minute) of the standard being counted) and $V$ is the volume of the sample. The factor 2.22 is a conversion factor from DPM to pCi. Samples were decay corrected to the collection date/time based on the half-life of ${ }^{222} \mathrm{Rn}$.

\subsection{Radon-222 from Sediment Samples}

To account for hyporheic zone contributions, sediment samples were collected at several locations by digging approximately $10 \mathrm{~cm}$ below the streambed with a trowel. The samples were dried for two days at $100{ }^{\circ} \mathrm{C}$ and then sieved into different sediment sizes: gravel $(>2 \mathrm{~mm})$, coarse-medium sand $(2 \mathrm{~mm}-300 \mu \mathrm{m})$, fine-very fine sand $(300-63 \mu \mathrm{m})$, and silt $(<63 \mu \mathrm{m})$. Sediment in the size category $>2 \mathrm{~mm}$ was not used.

Three grams of each grain size category for each sample were placed in a $20 \mathrm{~mL}$ glass vial, and the vial was filled to the $10 \mathrm{~mL}$ point with deionized water, followed by $10 \mathrm{~mL}$ of liquid scintillation cocktail. Laboratory control samples were made using a soil-based standard with a certified value of uranium and thorium content, deionized water filled to the $10 \mathrm{~mL}$ point, and $10 \mathrm{~mL}$ of mineral oil. Blanks were made using pure silica sand (considered to be uranium and thorium free), water filled to the $10 \mathrm{~mL}$ point, and $10 \mathrm{~mL}$ of mineral oil. 
By approximating porosity and rock density, an emanation rate, $E(\mathrm{~Bq} / \mathrm{kg})$, can be calculated from the equation

$$
E=\frac{\theta \times C_{e q}}{(1-\theta) \rho}
$$

where $\theta$ is porosity, $\rho$ is density, and $C_{e q}$ is an empirical estimate of the equilibrium concentration of ${ }^{222} \mathrm{Rn}$ activity in groundwater $[27,39]$.

The ${ }^{222} \mathrm{Rn}$ emanation rate, $E$, is related to the ${ }^{222} \mathrm{Rn}$ production rate, $\gamma$, in $\mathrm{Bq} / \mathrm{L}_{\text {day }}{ }^{-1}$, by

$$
\gamma=\frac{E(1-\theta) \rho \lambda}{\theta}
$$

where $\rho$ is the density of the solid, and $\lambda$ is the decay constant [30].

\subsection{Xenon Tracer}

Xenon was used as a tracer to calculate ${ }^{222} \mathrm{Rn}$ loss to the atmosphere in this stream survey, along with $\mathrm{SF}_{6}$. A comparison of results for these tracers is reported in Benson et al. [35]. Briefly, the Xe tracer was introduced continuously for three days through a one meter length of gas permeable tubing (weighed down by a chain). A regulator connected to a lecture bottle containing Xe gas allowed the slow release of Xe into the tubing (the efficiency of dissolution was nearly 100\%). Three times a day (morning, afternoon, and evening) for three days, the survey team took samples from the left and right banks and the center of the stream at eight locations downstream and one upstream of the Xe introduction location. The samples were analyzed by noble gas membrane inlet mass spectrometry (NG-MIMS), which measures dissolved gasses by pumping the water from the sample through a semipermeable membrane and detecting Xe in the extracting gas using a residual gas analyzer [40].

\subsection{Stream Flow}

Stream discharge was measured at five locations along the study reach using a FP111 Global Water ${ }^{\mathrm{TM}}$ flow probe (Global Water Instrumentation, College Station, TX, USA). The probe calculates an average stream velocity over the depth of the water column, which was measured at $0.3 \mathrm{~m}$ intervals across the width of the stream. Stream discharge $(Q)$ is calculated by multiplying the cross-sectional areas by the flow velocities and summing the resulting discharge for each section.

\section{Results}

Initial surveys of ${ }^{222} \mathrm{Rn}$ in well samples and stream samples distributed around Martis Valley showed uniformly high ${ }^{222} \mathrm{Rn}$ activities in wells and mostly very low activities in streams (Tables A1 and A2). Radon-222 activities in well samples had a mean value of $804 \mathrm{pCi} / \mathrm{L}$. Such high activities are typical for groundwater in basins with sediments derived from granitic and volcanic rocks [41,42].

Samples from the Truckee River, Donner Creek, tributaries to Martis Creek, and several locations along the main stem of Martis Creek were consistently close to, or below, the detection limit of about $20 \mathrm{pCi} / \mathrm{L}$. These locations are therefore not in the vicinity of points of significant groundwater discharge to the streams. Two exceptions to the low activities in stream water were a persistent pool in Middle Martis Creek near Highway 267 (Figure 1), and a reach along Martis Creek near the border between the Army Corps of Engineers Martis Creek Wildlife area and the Lahontan Golf Club (Lahontan Dr; Figure 2). The upstream reach of Martis Creek was thus chosen for a more detailed survey and a tracer test. 


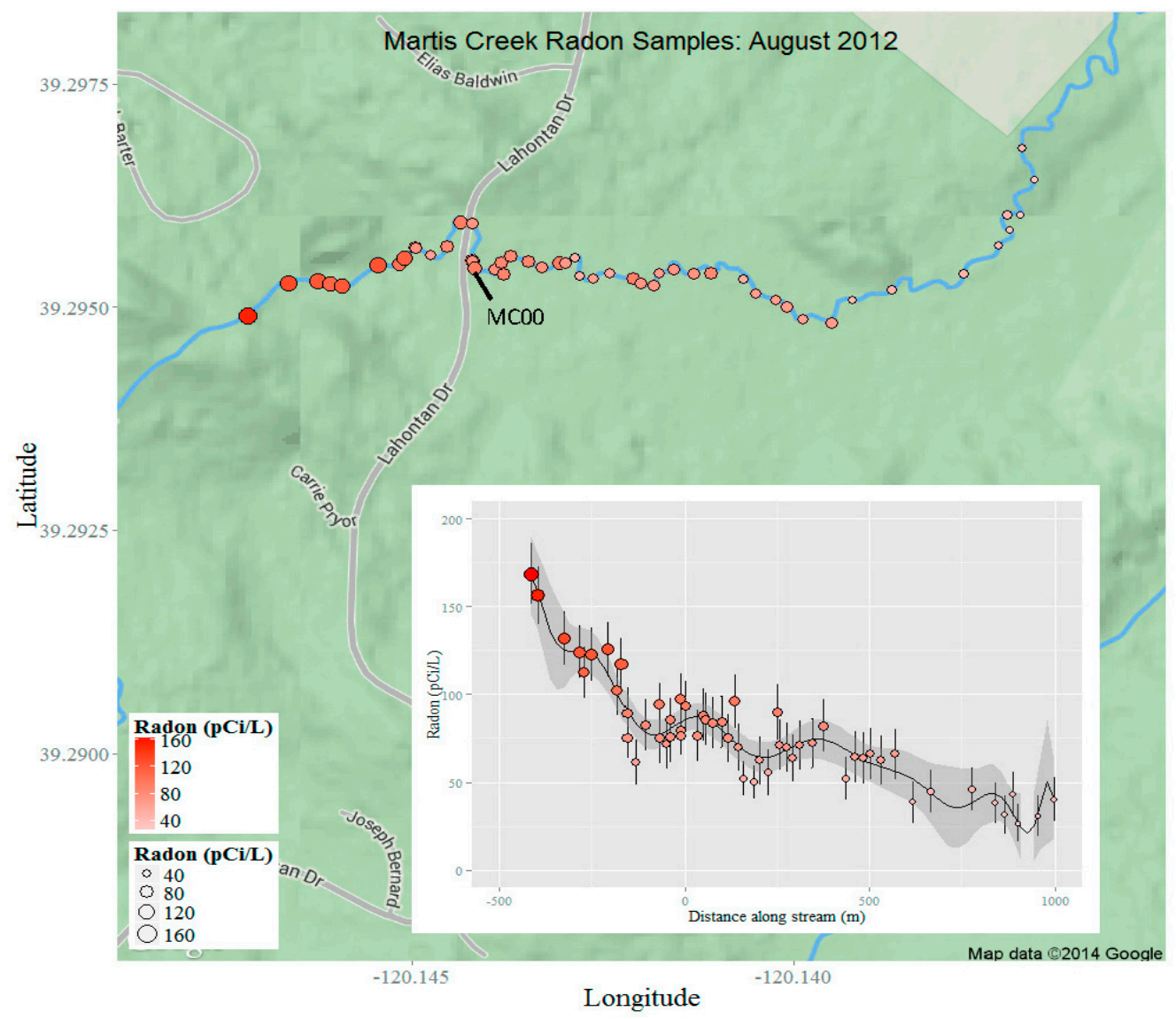

Figure 2. ${ }^{222} \mathrm{Rn}$ activity levels for the mid-August 2012 stream survey. Inset: ${ }^{222} \mathrm{Rn}$ as a function of distance downstream; the shaded interval is a local polynomial regression (LOESS) fit. Distance 0 is the location MC00 (Table 1).

\subsection{Radon-222 in Groundwater}

Groundwater samples were analyzed from both monitoring and production well sources across Martis Valley in December 2011, June 2012, and October 2012. Results of ${ }^{222} \mathrm{Rn}$ activities in wells and springs from Martis Valley are shown in Figure A1 (in Appendix A) and in Table A1. Wells available for sampling in this study are deep and long-screened. The wells nearest to Martis Creek ( $\mathrm{N}$ and $\mathrm{O}$, Figure A1a) had ${ }^{222} \mathrm{Rn}$ activities $>800 \mathrm{pCi} / \mathrm{L}$ in both June and December. Radon-222 activities measured in these wells likely represent activity in the deep portion of the aquifer system, while a significant component of the groundwater discharge to streams is likely to come from the shallow portion of the aquifer system, where well sampling points are not available. Spring samples have somewhat lower ${ }^{222} \mathrm{Rn}$ activities and may be more representative of the shallower groundwater flow system. In particular, Spring $X$ is located near the headwater area of Middle Martis Creek and had a mean activity of $528 \mathrm{pCi} / \mathrm{L}$, while Spring $\mathrm{Y}$, in the downstream portion of the study area, had an activity of $322 \mathrm{pCi} / \mathrm{L}$ (Figure A1b). A representative value of $400 \mathrm{pCi} / \mathrm{L}$ was used as an estimate of the ${ }^{222} \mathrm{Rn}$ activity in groundwater that contributes to the stream $\left(c_{i}\right)$, based on spring results and the sediment incubation experiments.

\subsection{Radon-222 in Surface Water}

Stream water samples were collected at key locations in December 2011, June 2012, and March and April 2013. In addition, two stream surveys with closely spaced sampling points were performed in July and August 2012 (Tables 1 and A2, Figures 1,2 and A2). As a general trend, ${ }^{222} \mathrm{Rn}$ activities decreased with distance downstream (Figure 2 inset). The stream reach selected for intensive study 
(mid-August 2012), was chosen based on the results of the preliminary surveys. During the mid-August stream survey, many stream samples had activities greater than $60 \mathrm{pCi} / \mathrm{L}$ in the reaches of the stream on Lahontan Golf Club property (IDs MC-17 through MC14 Table 1), and samples above MC-09 had activities greater than $100 \mathrm{pCi} / \mathrm{L}$, clearly indicating groundwater influx over these reaches.

A final stream survey was performed in March/April 2013 (Figure A3 and Table A2), upstream from the August 2012 survey. No precipitation occurred in the preceding few days before sampling. Because of higher discharge from snowpack runoff, which tends to peak in late March or early April [43,44], ${ }^{222} \mathrm{Rn}$ activities in the stream were lower; however, relatively high activities were observed near the same locations during runoff and baseflow seasons.

Table 1. Downstream survey of measured ${ }^{222} \mathrm{Rn}$ activity levels in Martis Creek.

\begin{tabular}{|c|c|c|c|c|}
\hline Sample ID & $\begin{array}{l}\text { Survey Distance }{ }^{1,2} \text { from } \\
\text { Xe Injection Point (m) }\end{array}$ & Collection Date & Act (pCi/L) & Error $95 \% \mathrm{CI}$ \\
\hline MC-17 & -415 & $08 / 15 / 12$ & 168.7 & 17.14 \\
\hline MC-16 & -396 & $08 / 15 / 12$ & 156.3 & 16.61 \\
\hline MC-15 & -324 & 08/15/12 & 132.0 & 15.43 \\
\hline MC-14 & -282 & $08 / 15 / 12$ & 124.2 & 15.07 \\
\hline MC-13 & -269 & 08/15/12 & 112.6 & 14.48 \\
\hline MC-12 & -252 & $08 / 15 / 12$ & 122.6 & 15.12 \\
\hline MC-11 & -205 & $08 / 15 / 12$ & 125.5 & 15.35 \\
\hline MC-10 & -182 & $08 / 15 / 12$ & 102.2 & 14.06 \\
\hline MC-09 & -170 & $08 / 15 / 12$ & 117.0 & 15.01 \\
\hline MC-08 & -155 & $08 / 14 / 12$ & 89.0 & 15.13 \\
\hline MC-08 & -155 & $08 / 16 / 12$ & 75.1 & 11.33 \\
\hline MC-07 & -132 & 08/14/12 & 61.3 & 13.03 \\
\hline MC-06 & -107 & 08/14/12 & 82.5 & 14.79 \\
\hline MC-05 & -70 & 08/14/12 & 75.1 & 14.30 \\
\hline MC-05 & -70 & $08 / 16 / 12$ & 94.1 & 12.49 \\
\hline MC-04 & -50 & 08/14/12 & 71.8 & 14.11 \\
\hline MC-03 & -40 & 08/14/12 & 75.6 & 14.49 \\
\hline MC-03 & -40 & 08/16/12 & 85.8 & 11.92 \\
\hline MC-01 & -11 & 08/15/12 & 97.3 & 14.60 \\
\hline MC-01 & -11 & 08/16/12 & 79.7 & 11.50 \\
\hline MC-01 & -11 & $08 / 16 / 12$ & 76.4 & 10.77 \\
\hline MC00 & 0 & 08/15/12 & 93.4 & 14.27 \\
\hline MC01 & 35 & $08 / 15 / 12$ & 76.6 & 14.29 \\
\hline MC02 & 49 & $08 / 15 / 12$ & 88.3 & 15.09 \\
\hline MC03 & 56 & 08/15/12 & 85.9 & 14.83 \\
\hline MC04 & 76 & 08/15/12 & 83.8 & 14.61 \\
\hline MC05 & 99 & $08 / 15 / 12$ & 84.4 & 14.58 \\
\hline MC06 & 116 & $08 / 15 / 12$ & 75.1 & 13.81 \\
\hline MC07 & 136 & $08 / 15 / 12$ & 95.8 & 15.25 \\
\hline MC08 & 146 & 08/15/12 & 69.9 & 13.27 \\
\hline MC09 & 157 & $08 / 15 / 12$ & 52.1 & 9.67 \\
\hline MC10 & 187 & $08 / 15 / 12$ & 50.1 & 9.46 \\
\hline MC11 & 204 & $08 / 15 / 12$ & 62.3 & 13.71 \\
\hline MC12 & 224 & $08 / 15 / 12$ & 55.5 & 13.03 \\
\hline MC13 & 250 & 08/15/12 & 89.8 & 15.76 \\
\hline MC14 & 262 & $08 / 15 / 12$ & 71.2 & 14.24 \\
\hline MC15 & 275 & 08/15/12 & 69.9 & 14.07 \\
\hline MC16 & 291 & 08/15/12 & 63.9 & 13.50 \\
\hline MC17 & - & 08/15/12 & 71.2 & 14.03 \\
\hline MC18 & 345 & $08 / 15 / 12$ & 72.4 & 14.06 \\
\hline MC19 & 376 & $08 / 15 / 12$ & 82.2 & 14.75 \\
\hline MC20 & 436 & $08 / 15 / 12$ & 52.1 & 12.20 \\
\hline MC21 & 462 & 08/15/12 & 64.2 & 14.50 \\
\hline MC22 & 485 & $08 / 15 / 12$ & 63.7 & 14.38 \\
\hline
\end{tabular}


Table 1. Cont.

\begin{tabular}{ccccc}
\hline Sample ID & $\begin{array}{c}\text { Survey Distance } \\
\text { Xe Injection Point } \mathbf{1} \text { (m) }\end{array}$ & Collection Date & Act (pCi/L) & Error 95\% CI \\
\hline MC23 & 503 & $08 / 15 / 12$ & 66.3 & 14.53 \\
MC24 & 532 & $08 / 15 / 12$ & 62.6 & 14.14 \\
MC25 & 570 & $08 / 15 / 12$ & 65.9 & 14.36 \\
MC26 & 619 & $08 / 15 / 12$ & 38.5 & 11.68 \\
MC27 & 665 & $08 / 15 / 12$ & 44.6 & 12.23 \\
MC28 & 778 & $08 / 15 / 12$ & 46.0 & 12.30 \\
MC29 & 837 & $08 / 15 / 12$ & 38.2 & 11.44 \\
MC30 & 863 & $08 / 15 / 12$ & 31.5 & 10.66 \\
MC31 & 885 & $08 / 15 / 12$ & 43.0 & 12.48 \\
MC32 & 899 & $08 / 15 / 12$ & 26.7 & 10.73 \\
MC33 & 955 & $08 / 15 / 12$ & 31.0 & 11.29 \\
MC34 & 997 & 40.2 & 12.37 \\
\hline
\end{tabular}

Notes: ${ }^{1}$ Negative distances are upstream and positive distances are downstream from the Xe introduction point (MC00). ${ }^{2}$ Two dashes (-) denote no distance recorded.

\subsection{Hyporheic Sediment Results}

Sediment samples were collected from locations MC23 and MC34, where ${ }^{222}$ Rn activities in water samples were somewhat higher than expected, based on comparison of the Xe and ${ }^{222} \mathrm{Rn}$ concentrations. For each of the samples, the sediment was divided into four particle size categories (coarse sediments $>2 \mathrm{~mm}$ were not used). Each of these categories shows relatively little ${ }^{222} \mathrm{Rn}$ contribution to the stream, with sediment from MC23 contributing 112 to $192 \mathrm{pCi} / \mathrm{kg}$, and sediment from MC34 contributing 177 to $264 \mathrm{pCi} / \mathrm{kg}$ (Table 2). These contributions are consistent with those Cox et al. [39] found in sediments from nearby Squaw Creek, and those reported by Cook et al. [27] for sediments from the Cockburn River in Australia.

Based on the decay rate of ${ }^{222} \mathrm{Rn}$, these activities should be within $10 \%$ of steady-state values where ${ }^{222} \mathrm{Rn}$ emanation is balanced by ${ }^{222} \mathrm{Rn}$ decay. Assuming a porosity of 0.4 and a sediment density of $2.9 \mathrm{~g} / \mathrm{cm}^{3}$, these emanation rates result in an equilibrium ${ }^{222} \mathrm{Rn}$ concentration between 479 and $1147 \mathrm{pCi} / \mathrm{L}$, following Equations (2) and (3). This is consistent with the observed ${ }^{222} \mathrm{Rn}$ activities in the groundwater. Higher emanation rates and equilibrium concentrations are found from the silt fraction of these sediments, commonly associated with higher concentrations of uranium and thorium [45]. Variation in measured ${ }^{222} \mathrm{Rn}$ activities and production rates may be related to sediment properties observed in the Martis Creek basin and varying $U$ concentrations of fine- and coarse-grained sediments.

Hyporheic zone contribution to ${ }^{222} \mathrm{Rn}$ activity in the stream cannot be quantified directly because the lateral extent and thickness of the hyporheic zone and the residence time of water in the hyporheic zone are not known. It is likely that the hyporheic zone is a source of ${ }^{222} \mathrm{Rn}$ activity, however, so the groundwater influx reported in the results can be considered a maximum flux. The contribution of the hyporheic zone to the stream ${ }^{222} \mathrm{Rn}$ budget is further evaluated in the discussion.

Table 2. Measured ${ }^{222} \mathrm{Rn}$ activity levels for sediment samples in the Martis Valley study area, where CI is confidence interval and $C_{e q}$ is equilibrium concentration.

\begin{tabular}{ccccccc}
\hline Sample ID & \multirow{2}{*}{ 222 Rn pCi/kg } & $\begin{array}{c}\mathbf{9 5 \%} \\
\text { CI }\end{array}$ & $\begin{array}{c}{ }^{222} \text { Rn Production } \\
\text { Rate, } \gamma \text { pCi/L/d }\end{array}$ & $\begin{array}{c}\mathbf{9 5 \%} \\
\text { CI }\end{array}$ & $C_{\text {eq }}{ }^{222} \mathbf{R n}$ pCi/L & 95\% CI \\
\hline MC23 $(2 \mathrm{~mm}-300 \mu \mathrm{m})$ & 111.61 & 4.17 & 88.6 & 3.3 & 486 & 18 \\
MC23 $(300-63 \mu \mathrm{m})$ & 110.11 & 4.16 & 87.4 & 3.3 & 479 & 18 \\
MC23 $(<63 \mu \mathrm{m})$ & 191.69 & 4.75 & 152.1 & 3.8 & 834 & 21 \\
MC34 $(2 \mathrm{~mm}-300 \mu \mathrm{m})$ & 176.68 & 4.65 & 140.2 & 3.7 & 769 & 20 \\
MC34 $(300-63 \mu \mathrm{m})$ & 215.22 & 4.90 & 170.8 & 3.9 & 936 & 21 \\
MC34 $(<63 \mu \mathrm{m})$ & 263.76 & 5.21 & 209.3 & 4.1 & 1147 & 23 \\
\hline
\end{tabular}




\subsection{Xenon Tracer}

Xe was introduced continuously at MC00 (at $39.2956^{\circ} \mathrm{N}, 120.1442^{\circ} \mathrm{W}$ ), in a reach of Martis Creek where relatively high ${ }^{222} \mathrm{Rn}$ activity had been observed. While the tracer was introduced, it mixed into the flowing water relatively quickly and thoroughly, showing little variation across the width of the stream. The Xe transect along the eight stations downstream showed a relatively smooth, exponential decrease in Xe concentration as Xe degassed from the stream $\left(R^{2}=0.994\right.$; Figure A4). Application of the one-dimensional (1D) advection-dispersion equation assuming first-order decay of a continuously released solute results in a value of the mean reaeration coefficient $(K)$ of $40 \mathrm{day}^{-1}$, as reported in Benson et al. [35]. The degassing constant $(k)$ for Xe can be calculated by multiplying $K\left(\right.$ day $\left.^{-1}\right)$ by stream depth, for which the range over the experimental reach was measured at 0.08 to $0.24 \mathrm{~m}$ with a mean of $0.16 \mathrm{~m}$. The rates found vary between 1.9 and $9.0 \mathrm{~m} /$ day, with the variance due to stream depth and, to a lesser extent, to the nature of the creek-there are some deep pools, some riffles, some shallower areas, and some areas with dense riparian vegetation. (This approach to estimating the degassing constant does not take dilution by groundwater into account; another approach to estimating $k$ is presented in the Discussion section, below.) For example, relatively more tracer degassing (per $\mathrm{m}$ ) occurred between MC27 and MC29 than occurred elsewhere along the creek. Escape of Xe from the stream to the atmosphere is similar to that of ${ }^{222} \mathrm{Rn}$, due to comparable physical behavior and atomic weight. The degassing constant for ${ }^{222} \mathrm{Rn}$ was calculated by multiplying the degassing constant for $\mathrm{Xe}$ by the ratio of the diffusion coefficients, resulting in $k_{\mathrm{Rn}} / k_{\mathrm{Xe}}$ of 0.75 .

\subsection{Stream Discharge}

Measured discharge at five locations along the survey reach indicates that discharge increases from $3567 \mathrm{~m}^{3} /$ day $\left(0.04 \mathrm{~m}^{3} / \mathrm{s}\right)$ approximately $200 \mathrm{~m}$ upstream of the tracer introduction location (at MC-10) to $5444 \mathrm{~m}^{3} /$ day $\left(0.06 \mathrm{~m}^{3} / \mathrm{s}\right.$; average of three measurements) at MC34, approximately $1000 \mathrm{~m}$ downstream. Since no tributaries or other sources of inflow are present along the study reach, the observed increase in flow can be attributed to groundwater influx. A similar range in discharge and in discharge increase was measured in Martis Creek near the Lahontan development in 2002 (3278 $\mathrm{m}^{3} /$ day to $4575 \mathrm{~m}^{3}$ /day) [37]. However, groundwater discharge can vary daily due to evapotranspiration or on shorter time scales in response to precipitation or headwater melting events. There is considerable uncertainty in these low discharge measurements (estimated at 15\% uncertainty based on repeat measurements) and the observed increases in discharge are therefore associated with relatively high uncertainty.

\section{Discussion}

The change in flux of a dissolved gas with distance downstream is a balance between the flux into the stream from groundwater and hyporheic zone sediments and the flux out of the stream due to evaporation losses, degassing (volatilization), decay, and losses to the hyporheic zone, as represented by the equation [27]

$$
Q \frac{\mathrm{d} c}{\mathrm{~d} x}=I\left(c_{i}-c\right)+w E c-k w c-d w \lambda c+\frac{\gamma h w \theta}{1+\lambda t_{h}}-\left[\frac{\lambda h w \theta}{1+\lambda t_{h}}\right] c
$$

where, at time $t, Q$ is stream discharge $\left(\mathrm{m}^{3} /\right.$ day), $I$ is influx $\left(\mathrm{m}^{3} /\right.$ day), $c_{i}$ is the initial ${ }^{222} \mathrm{Rn}$ activity $(\mathrm{pCi} / \mathrm{L})$ of groundwater discharge to the stream, $c$ is ${ }^{222} \mathrm{Rn}$ activity $(\mathrm{pCi} / \mathrm{L})$ at location $x, w$ is the mean stream width (m), $E$ is the evaporation rate (m/day), $k$ is the degassing constant (m/day), $d$ is the mean stream depth $(\mathrm{m}), \lambda$ is the radioactive decay constant $\left(\mathrm{day}^{-1}\right)$ for ${ }^{222} \mathrm{Rn}, \gamma$ is the production rate for ${ }^{222} \mathrm{Rn}$ (pCi/L/day) within the hyporheic zone, $\theta$ is the porosity of sediments in the hyporheic zone, $h(\mathrm{~m})$ is the thickness of the hyporheic zone, and $t_{h}$ is the mean residence time of water (day) within the hyporheic zone [27]. 
Since the time the stream water takes to go from the tracer injection point to the end of the stream survey is negligible compared to the half-life of ${ }^{222} \mathrm{Rn}$, the term $d w \lambda c$ can be eliminated. Additionally, if production in the hyporheic zone is effectively zero (as demonstrated later in this section), the concentration of ${ }^{222} \mathrm{Rn}$ activity in the hyporheic zone porewater will be equal to that in the stream water, and the equation may be simplified by eliminating the last two terms $\frac{\gamma h w \theta}{1+\lambda t_{h}}-$ $\left[\frac{\lambda h w \theta}{1+\lambda t_{h}}\right] c[33]$. The equation may be further simplified if evaporation is neglected, which, in the case of Martis Creek, is appropriate, since the creek experiences minimal evaporation over the short study reach. Stream width $w$ varies from 117 to $658 \mathrm{~cm}$, and the evaporation rate $E$ for streams the size of Martis Creek is estimated to be between $10^{-3}$ and $10^{-2} \mathrm{~m} /$ day. Measured ${ }^{222} \mathrm{Rn}$ activities $c$ vary from $27 \mathrm{pCi} / \mathrm{L}$ to $169 \mathrm{pCi} / \mathrm{L}$. In that case, the term $w E c$ is negligibly small, which leaves

$$
Q \frac{\mathrm{d} c}{\mathrm{~d} x}=I\left(c_{i}-c\right)-k w c .
$$

Rearranging terms to solve for I gives

$$
I=\left(Q \frac{\mathrm{d} c}{\mathrm{~d} x}+k w c\right)\left[\frac{1}{\left(c_{i}-c\right)}\right]
$$

which is used to calculate the groundwater influx $(I)$ to Martis Creek. Stream discharge $(Q)$, gas transfer velocity $(k)$, mean stream width $(w)$, and stream ${ }^{222} \mathrm{Rn}$ activity $(c)$ were all measured, while groundwater ${ }^{222} \mathrm{Rn}$ activity $\left(c_{i}\right)$ was estimated to be $400 \mathrm{pCi} / \mathrm{L}$ (Table 3 ). To evaluate the uncertainty on the estimated groundwater discharge patterns, additional analyses were performed with groundwater ${ }^{222} \mathrm{Rn}$ activities of $200 \mathrm{pCi} / \mathrm{L}$ or $800 \mathrm{pCi} / \mathrm{L}$.

Table 3. Parameters used to model groundwater influx.

\begin{tabular}{ccc}
\hline Variable & Range & Description \\
\hline$c$ & $27-169$ & Measured ${ }^{222} \mathrm{Rn}$ activity $(\mathrm{pCi} / \mathrm{L})$ \\
$Q o$ & 0.05 & Initial Stream Discharge $\left(\mathrm{m}^{3} / \mathrm{s}\right)$ \\
$d x$ & $7-113$ & Step Size $(\mathrm{m})$ \\
$w$ & $1.6-3.6$ & Stream Width $(\mathrm{m})$ \\
$k$ & 2.16 & Gas Transfer Velocity $(\mathrm{m} /$ day) \\
$w \times k$ & 7.6 & Optimized Effective Gas Exchange Coefficient $\left(\mathrm{m}^{2} /\right.$ day $)$ \\
$C i$ & 400 & Groundwater ${ }^{222} \mathrm{Rn}$ activity $(\mathrm{pCi} / \mathrm{L})$ \\
$v$ & $0.16-0.65$ & Stream velocity $($ for K; $\mathrm{m} / \mathrm{s})$ \\
\hline
\end{tabular}

Groundwater inflow for each of the 50 sections was estimated by minimizing the difference between the measured and modeled ${ }^{222} \mathrm{Rn}$ concentrations. Simultaneously, the xenon concentration was modeled in the stream, decreasing due to gas exchange between the stream and the atmosphere and dilution by groundwater discharge. The xenon concentration at the first xenon survey location (MC04) was fixed at 44 nanomol/L. Stream discharge was fixed to the measured stream discharge $\left(4380 \mathrm{~m}^{3}\right.$ /day) at MC-01, $11 \mathrm{~m}$ upstream of the xenon injection location. Stream flow upstream of MC-01 was calculated by subtracting the estimated groundwater inflow. This approach also allowed for the effective gas exchange coefficient $(k w)$ to be optimized, considering xenon dilution by groundwater inflow. The objective $O$ for the optimization was the sum of squared differences between the measured and modeled ${ }^{222} \mathrm{Rn}$ and xenon concentrations, divided by the measurement uncertainty:

$$
O=\sum_{i=2}^{51}\left(\frac{{ }^{222} \mathrm{Rn}_{i, \text { modeled }}-{ }^{222} \mathrm{Rn}_{i, \text { measured }}}{{ }^{222} \mathrm{Rn}_{i, \text { uncertainty }}}\right)+\sum_{j=2}^{8}\left(\frac{\mathrm{X}_{j, \text { modeled }}-\mathrm{X}_{j, \text { measured }}}{X \mathrm{e}_{j, \text { uncertainty }}}\right) .
$$

Figure 3 shows the resulting modeled ${ }^{222} \mathrm{Rn}$ and Xe concentrations in Martis creek, together with the measured concentrations. The Xe concentrations are mostly well captured by the model, and are 
within the measurement uncertainty $(8 \%)$. Differences between modeled and measured concentrations indicate variation in stream morphology resulting in variable gas exchange velocities along the $1 \mathrm{~km}$ stretch under investigation.

Measured ${ }^{222} \mathrm{Rn}$ concentrations are generally well captured by the forward model. Measured ${ }^{222} \mathrm{Rn}$ concentrations show stronger decreases than the model in the first $500 \mathrm{~m}$ of the investigated stretch, upstream of the Xe introduction. These decreases could indicate that the gas exchange rate was higher in this section. Modeled ${ }^{222} \mathrm{Rn}$ concentrations with either $400 \mathrm{pCi} / \mathrm{L}$ or $800 \mathrm{pCi} / \mathrm{L}$ as groundwater ${ }^{222} \mathrm{Rn}$ concentration do not capture the increase between 250 and $200 \mathrm{~m}$ before the Xe injection location and predict no groundwater increase over the interval. If a groundwater ${ }^{222} \mathrm{Rn}$ concentration of $200 \mathrm{pCi} / \mathrm{L}$ is assumed, groundwater contributions are predicted between $-325 \mathrm{~m}$ and $-250 \mathrm{~m}$, as discussed further below. Also, downstream of the Xe injection location, there appear to be sections where ${ }^{222} \mathrm{Rn}$ decreases more rapidly over short intervals than the smooth decrease of Xe over larger intervals. As a consequence, the estimated groundwater discharge could be too low. These nuances show the importance of an introduced tracer constraint on the gas exchange rate. The optimized gas transfer velocity $k(2.16 \mathrm{~m} /$ day $)$ is at the low end of the range previously estimated, considering a stream width $w$ of $3.5 \mathrm{~m}$.

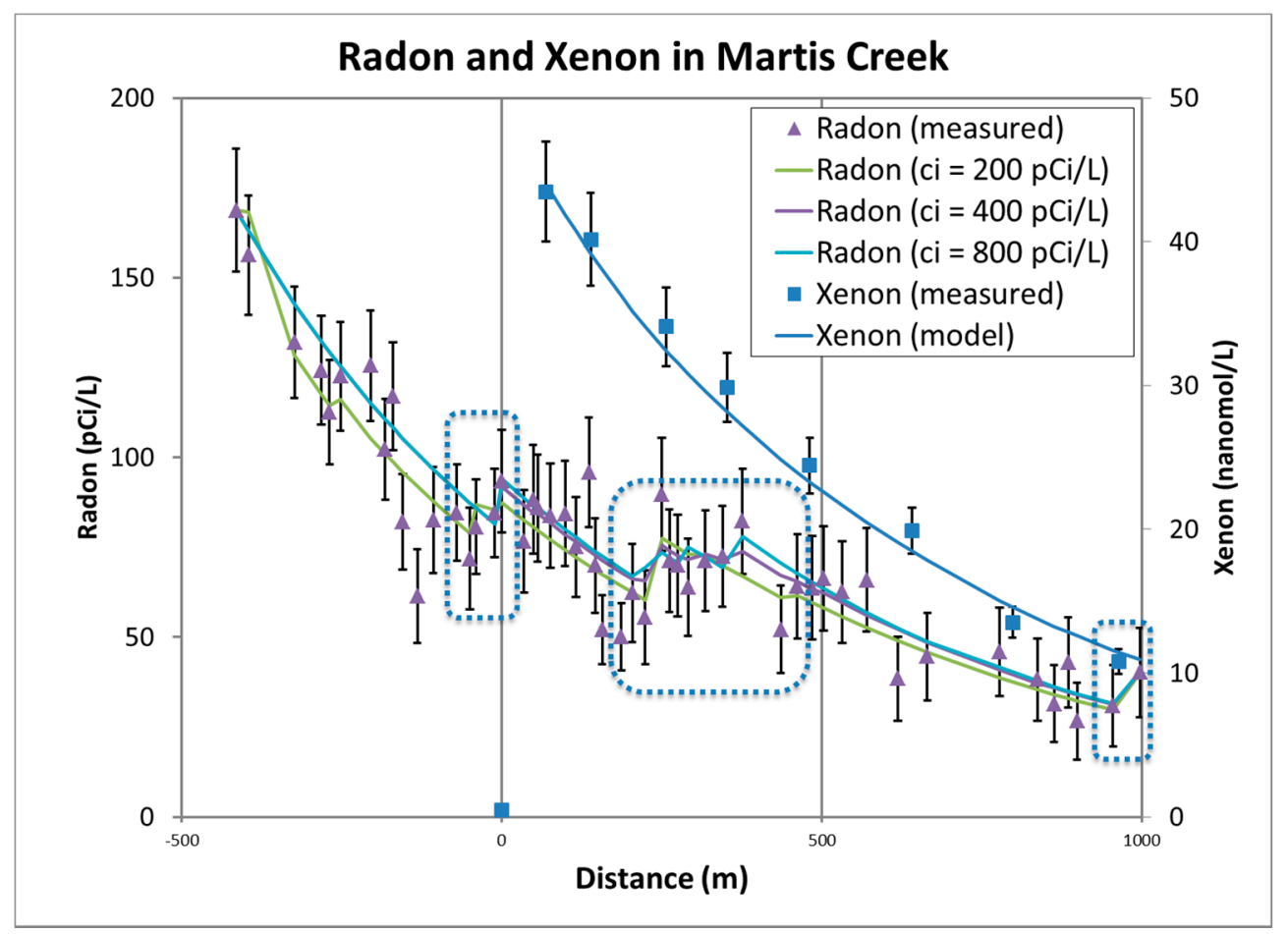

Figure 3. Measured ${ }^{222} \mathrm{Rn}$ activities (purple triangles) and Xe concentrations (blue squares) in the study reach are shown along with the predicted model values for ${ }^{222} \mathrm{Rn}$ for different values of the groundwater ${ }^{222} \mathrm{Rn}$ concentration $c_{i}$ (purple, green, and blue lines) and Xe (blue line). Dashed rectangles highlight stretches of Martis Creek where groundwater inflow is detected. Distance 0 shows the tracer introduction location (MC00 in Table 1), distance $500 \mathrm{~m}$ is the approximate location of MC23 and distance $1000 \mathrm{~m}$ is the approximate location of MC34 (Table 1).

Although Xe and ${ }^{222} \mathrm{Rn}$ show roughly similar, exponentially decreasing patterns, the calculations indicate that some groundwater influx is required at locations throughout the study reach to maintain observed ${ }^{222} \mathrm{Rn}$ levels. Groundwater influxes are estimated at the location of Xe injection (0-35 m, $15 \mathrm{~m}^{3} /$ day $\left./ \mathrm{m}\right), 250 \mathrm{~m}$ downstream $\left(8 \mathrm{~m}^{3} /\right.$ day $/ \mathrm{m}$ for $\left.26 \mathrm{~m}\right)$, and more gradually between 320 and $500 \mathrm{~m}\left(0-3 \mathrm{~m}^{3} /\right.$ day $\left./ \mathrm{m}\right)$. A small influx of $4 \mathrm{~m}^{3} /$ day $/ \mathrm{m}$ is captured at $955 \mathrm{~m}$. These groundwater influx locations are identified as independent of the groundwater ${ }^{222} \mathrm{Rn}$ concentration 
$c_{i}$. The magnitude of groundwater inflow is inversely related to the assumed groundwater ${ }^{222} \mathrm{Rn}$ concentration. The uncertainty of the stream flow measurements is such that neither the highest nor the lowest groundwater ${ }^{222} \mathrm{Rn}$ concentration can be rejected as unlikely (Figure 4 ). If a groundwater ${ }^{222} \mathrm{Rn}$ concentration of $200 \mathrm{pCi} / \mathrm{L}$ is assumed, the optimization procedure finds a solution with significant groundwater inflow between -400 and $-180 \mathrm{~m}$ along this stretch of Martis Creek. Flow measurements are not available to confirm this result.

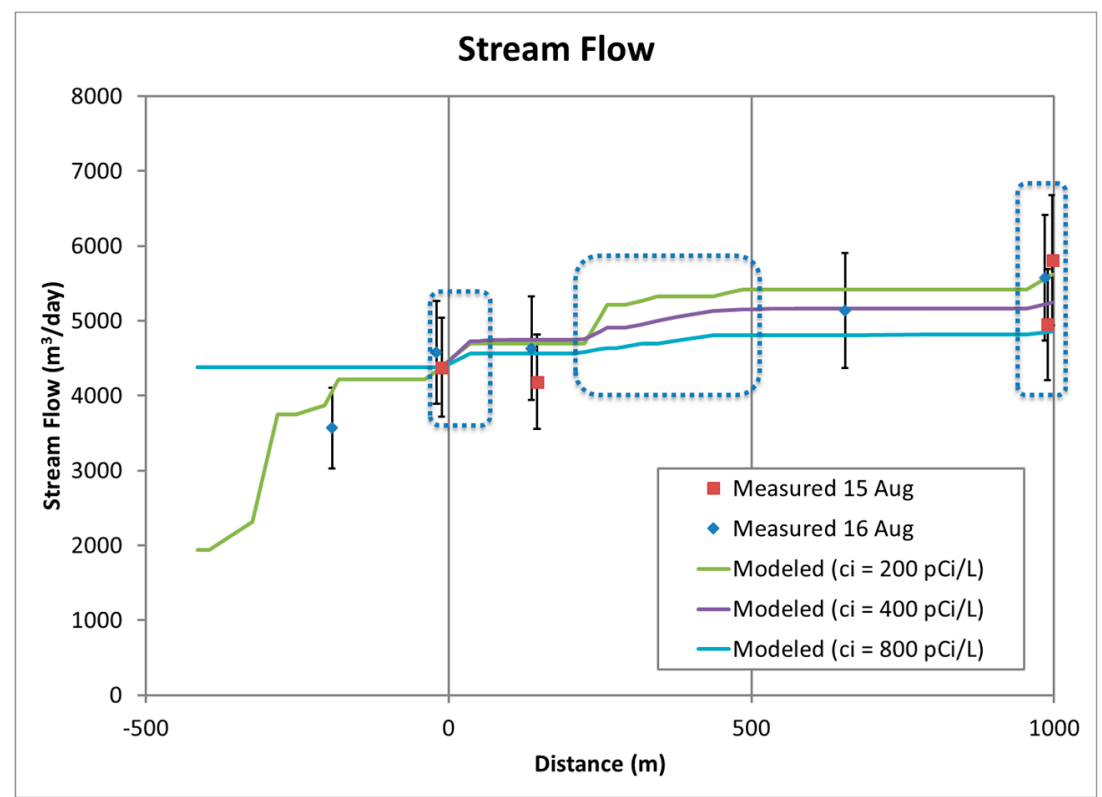

Figure 4. Stream discharge along Martis Creek study area measured with a FP111 flow probe (red squares and blue diamonds). Distance 0 shows the tracer introduction location (MC00, Table 1). Vertical error bars are $\pm 15 \%$, based on the typical reproducibility of low flow measurements. Modeled groundwater influx over the study reach is also shown for different values of the groundwater ${ }^{222} \mathrm{Rn}$ concentration $c_{i}$ (green, purple, and blue lines). Dashed rectangles highlight stretches of Martis Creek where groundwater inflow is detected.

To evaluate the contribution of the hyporheic zone to the ${ }^{222} \mathrm{Rn}$ budget of the stream, let us assume that the groundwater influx is negligible. In this special case, the ${ }^{222} \mathrm{Rn}$ concentration is given by Equation (8) (Equation (10) in [27]):

$$
c=\frac{\gamma h \theta}{\left(1+\lambda t_{h}\right)(k+\lambda d)+\lambda h \theta} .
$$

The ${ }^{222} \mathrm{Rn}$ concentration in the stream then depends on the production rate for ${ }^{222} \mathrm{Rn}$ within the hyporheic zone $(\gamma)$, the thickness of the hyporheic zone $(h)$, the porosity of sediments in the hyporheic zone $(\theta=0.4)$, the radioactive decay constant for ${ }^{222} \mathrm{Rn}\left(\lambda=0.18\right.$ day $\left.^{-1}\right)$, the mean residence time of water within the hyporheic zone $\left(t_{h}\right)$, the degassing constant $(k=2.16)$, and the mean stream depth $(d=0.16)$. The average of the measured hyporheic zone ${ }^{222} \mathrm{Rn}$ production rates is $180 \mathrm{pCi} / \mathrm{L} / \mathrm{d}$. The thickness of the hyporheic zone $(h)$ and the residence time of water in the hyporheic zone are unknown. Assuming a thickness equal to the stream depth $(0.16 \mathrm{~m})$ and an infinitely short residence time (which yields the highest hyporheic zone contribution) results in an equilibrium ${ }^{222} \mathrm{Rn}$ concentration in the stream of $5 \mathrm{pCi} / \mathrm{L}$. Assuming that the thickness of the hyporheic zone is four times larger results in a stream concentration of $20 \mathrm{pCi} / \mathrm{L}$. The dependence of the hyporheic zone contribution to the stream water concentration is illustrated in Figure A5. We conclude that the hyporheic zone contribution is relatively minor compared with the measured ${ }^{222} \mathrm{Rn}$ concentrations in the stream $(27-169 \mathrm{pCi} / \mathrm{L})$. 
The groundwater influx "hot spots" would be difficult to identify using physical flow measurements, as it would not be practical to measure discharge over the spatial scale and with the accuracy necessary to ascertain the level of spatial detail afforded by the ${ }^{222} \mathrm{Rn}$ results. While deployment of an extrinsic tracer may not be practical in many situations, measurement of ${ }^{222} \mathrm{Rn}$ is relatively easy and inexpensive, and allows identification of reaches where groundwater influx is occurring on a scale pertinent for ecological considerations.

The modeled cumulative stream flow increases from $4380 \mathrm{~m}^{3} /$ day at the injection location to $5175 \mathrm{~m}^{3}$ /day at a distance $1 \mathrm{~km}$ downstream (Figure 4). The calculated influx of groundwater is equivalent to $18 \%$ of the initial stream flow if a groundwater ${ }^{222} \mathrm{Rn}$ concentration of $400 \mathrm{pCi} / \mathrm{L}$ is assumed. Lower $(200 \mathrm{pCi} / \mathrm{L})$ or higher $(800 \mathrm{pCi} / \mathrm{L})$ groundwater ${ }^{222} \mathrm{Rn}$ concentrations result in higher $(28 \%)$ or lower $(11 \%)$ influxes of groundwater, respectively. Although the calculated groundwater influx values in this reach $\left(800 \mathrm{~m}^{3} /\right.$ day) are within the uncertainty ranges of the stream flow measurements made at various locations on August 15 and 16, the influx represents a critical portion of the annual discharge, as the importance of the persistence of the influx into the late summer and fall cannot be overstated. The presence of deep pools that act as refugia for fish and the moderating effect of groundwater discharge on temperature are recognized as controls on species distribution and total biomass [6-10].

These results indicate that influx of groundwater to the stream is heterogeneous and related to topographic or morphologic stream features. The study reach is within the transition of the stream from being well shaded, with a relatively steep gradient (2-3\%), and little anthropogenic alteration to having no overstory, with a low gradient $(<1 \%)$, and nearby features including a golf course and housing development. The meadow area within and downstream of the study reach has been altered by historical land use practices and, to a lesser extent, by current recreational activities.

Another significant transition is the degree of incision and preponderance of eroded banks within the study reach compared with within the upstream reach, where bank stability is bolstered by outcrops and boulders. Within the study reach, the pool and riffle morphology likely plays a role in streambed sediment distribution and re-aeration of ${ }^{222} \mathrm{Rn}$, but observations of individual pools and riffles during the experiment did not correlate with locations of groundwater input (e.g., between 200-350 m and at $950 \mathrm{~m}$ ) in an obvious manner. However, stream incision can cause an increase in the hydraulic gradient and result in groundwater drainage from the riparian sediments [46], and this likely plays a role in the spatial variability in groundwater discharge along Martis Creek.

\section{Conclusions}

Tracers and bio-indicators are important tools for researching groundwater-surface water interaction and groundwater-dependent ecosystems $[15,18,47] .{ }^{222} \mathrm{Rn}$ is a unique indicator of groundwater discharge $[15,18,27,28]$. In certain situations, both ${ }^{222} \mathrm{Rn}$ and ${ }^{4} \mathrm{He}$ [21] or ${ }^{14} \mathrm{C}[48]$ can pinpoint groundwater discharge locations, while confirming longer groundwater flow paths. More elaborate modeling approaches constrain the uncertainty of estimated groundwater inflow estimates [16] which were significant in this study. The additional use of an introduced tracer like xenon or $\mathrm{SF}_{6}$ [27] is essential for quantitative estimates of groundwater influx. Absent an introduced tracer, ${ }^{222} \mathrm{Rn}$ measurements are valuable for pinpointing groundwater influx on a small scale, as evidenced in this study, for regional assessments of groundwater-surface water interaction [17,22]. Radon-222 is also suitable for studying temporal variability of groundwater discharge [14] when repeated flux measurements are too time-consuming. Additional research incorporating detailed temperature measurements $[49,50]$ can constrain the importance and residence times of hyporheic exchange.

Martis Valley is categorized as medium priority by the California Statewide Groundwater Elevation Monitoring Program. With $128 \%$ population growth in the 2000 's and $90 \%$ of water used supplied from groundwater [36], understanding groundwater-surface water interaction in this basin is critical. The water budget relies on accurate numbers and, by utilizing geochemical methods, we are able to produce a more nuanced estimate of groundwater influx than by relying on physical flow measurements. In addition, groundwater management under the California Sustainable Groundwater 
Management Act [11] shall not result in "depletions of interconnected surface water that has significant and unreasonable adverse impacts on beneficial uses of the surface water". This requirement demands a detailed quantitative understanding of groundwater discharges to streams. Since a large proportion of Martis Creek's flow is from groundwater influx, this accuracy is necessary to maintain a healthy baseflow in Martis Creek during the dry months of the water year.

Acknowledgments: This work was performed under the auspices of the U.S. Department of Energy by Lawrence Livermore National Laboratory under Contract DE-AC52-07NA27344. The study was funded by the California State Water Resources Control Board Groundwater Ambient Monitoring and Assessment Program. Special thanks to Stephanie Urióstegui, who helped carry out field and analytical work. The manuscript was improved based on revisions suggested by three anonymous reviewers.

Author Contributions: Elizabeth Avery, Ate Visser, Jean Moran and Bradley Esser conceived and designed the experiments; Elizabeth Avery, Ate Visser, Jean Moran and Bradley Esser carried out field work. Elizabeth Avery and Richard Bibby performed the sample analyses; Elizabeth Avery, Richard Bibby, Ate Visser and Jean Moran analyzed the data; Elizabeth Avery, Ate Visser and Jean Moran wrote the paper.

Conflicts of Interest: The authors declare no conflict of interest.

\section{Appendix}

Table A1. Measured ${ }^{222} \mathrm{Rn}$ activity levels for wells and springs in the Martis Valley region corresponding to locations on Figures A1 and A2.

\begin{tabular}{cccc}
\hline Map ID & Collection Date & Act $(\mathbf{p C i} / \mathbf{L})$ & Error $\mathbf{9 5 \%}$ CI \\
\hline O & $12 / 19 / 11$ & 858 & 102 \\
K & $12 / 19 / 11$ & 419 & 30.3 \\
N & $12 / 19 / 11$ & 868 & 38.2 \\
E & $12 / 19 / 11$ & 1270 & 54.0 \\
G & $12 / 19 / 11$ & 772 & 65.3 \\
D & $12 / 19 / 11$ & 644 & 15.4 \\
C & $12 / 19 / 11$ & 362 & 22.7 \\
H & $12 / 19 / 11$ & 1180 & 25.8 \\
J & $12 / 20 / 11$ & 500 & 53.9 \\
L & $12 / 20 / 11$ & 1010 & 187 \\
A & $06 / 19 / 12$ & 687 & 27.6 \\
B & $06 / 19 / 12$ & 497 & 23.6 \\
C & $06 / 19 / 12$ & 463 & 22.9 \\
D & $06 / 19 / 12$ & 769 & 29.5 \\
E & $06 / 19 / 12$ & 1280 & 37.9 \\
F & $06 / 19 / 12$ & 786 & 29.8 \\
G & $06 / 19 / 12$ & 952 & 32.9 \\
H & $06 / 19 / 12$ & 1300 & 38.5 \\
I & $06 / 20 / 12$ & 606 & 24.9 \\
J & $06 / 20 / 12$ & 442 & 21.3 \\
K & $06 / 20 / 12$ & 543 & 23.6 \\
L & $06 / 20 / 12$ & 722 & 27.2 \\
M & $06 / 20 / 12$ & 9.19 & 4.23 \\
N & $06 / 20 / 12$ & 1130 & 33.9 \\
O & $06 / 20 / 12$ & 1230 & 35.6 \\
Z & $10 / 29 / 12$ & 720 & 27.5 \\
Z & $10 / 29 / 12$ & 739 & 27.9 \\
Y & $10 / 29 / 12$ & 322 & 18.7 \\
X & $10 / 29 / 12$ & 564 & 25.2 \\
X & $10 / 29 / 12$ & 491 & \\
\hline & & & \\
\hline
\end{tabular}


Table A2. Measured ${ }^{222} \mathrm{Rn}$ activity levels for surface water in the Martis Valley region.

\begin{tabular}{|c|c|c|c|c|}
\hline Sample ID & $\begin{array}{c}\text { Survey Distance }^{1,2} \text { from } \\
\text { Xe Injection Point (m) }\end{array}$ & $\begin{array}{l}\text { Collection } \\
\text { Date }\end{array}$ & $\begin{array}{c}\text { Act } \\
(\mathrm{pCi} / \mathrm{L})\end{array}$ & $\begin{array}{l}\text { Error } 95 \% \\
\quad \text { CI }\end{array}$ \\
\hline West Martis Creek @ gage & - & $12 / 19 / 11$ & 4.05 & 1.90 \\
\hline Truckee River@ Don. Cr & - & $12 / 20 / 11$ & 12.6 & 12.3 \\
\hline Martis Creek @ \#3 Bridge & - & $12 / 20 / 11$ & 57.5 & 36.3 \\
\hline Martis Creek at Hwy 267 & - & $12 / 20 / 11$ & 11.5 & 3.81 \\
\hline $\begin{array}{c}\text { Donner Creek (between Truckee R } \\
\text { and West R Rd) }\end{array}$ & - & $06 / 21 / 12$ & 2.17 & 2.94 \\
\hline $\begin{array}{l}\text { Truckee R (40 m dwnstrm of } \\
\text { Donner Cr. confl.) }\end{array}$ & - & $06 / 21 / 12$ & 2.43 & 3.00 \\
\hline $\begin{array}{l}\text { Martis Creek (upstream wooden } \\
\text { bridge @267) }\end{array}$ & - & $06 / 21 / 12$ & 2.20 & 2.98 \\
\hline N Fork American R. @ Iowa Hill & - & $06 / 21 / 12$ & 1.23 & 2.82 \\
\hline Mid Martis Cr. @ bridge & - & $07 / 09 / 12$ & 91.9 & 8.62 \\
\hline Martis Cr. Dwnstrm survey & - & $07 / 09 / 12$ & 8.92 & 3.41 \\
\hline Martis Cr. Dwnstrm survey & - & $07 / 09 / 12$ & 6.35 & 3.13 \\
\hline Martis Cr. Dwnstrm survey & - & $07 / 09 / 12$ & 8.49 & 3.41 \\
\hline Martis Cr. Dwnstrm survey & - & $07 / 09 / 12$ & 4.62 & 2.97 \\
\hline Martis Cr. Dwnstrm survey & - & $07 / 09 / 12$ & 12.9 & 3.94 \\
\hline Martis Cr. Dwnstrm survey & - & 07/09/12 & 11.4 & 3.81 \\
\hline Martis Cr. Dwnstrm survey & - & $07 / 09 / 12$ & 9.11 & 3.60 \\
\hline Martis Cr. Dwnstrm survey & - & $07 / 09 / 12$ & 11.2 & 3.86 \\
\hline Martis Cr. Dwnstrm survey & - & $07 / 09 / 12$ & 13.3 & 4.11 \\
\hline Martis Cr. Dwnstrm survey & - & $07 / 09 / 12$ & 6.96 & 3.44 \\
\hline Martis Cr. Dwnstrm survey & - & $07 / 09 / 12$ & 9.53 & 3.77 \\
\hline Martis Cr. Dwnstrm survey & - & $07 / 09 / 12$ & 8.73 & 3.71 \\
\hline Martis Cr. Dwnstrm survey & - & 07/09/12 & 4.20 & 3.17 \\
\hline Martis Cr. Dwnstrm survey & - & $07 / 09 / 12$ & 7.53 & 3.63 \\
\hline Martis Cr. Dwnstrm survey & - & $07 / 09 / 12$ & 7.85 & 3.69 \\
\hline Martis Cr. Upstream survey & - & $07 / 09 / 12$ & 14.9 & 4.50 \\
\hline Martis Cr. Dwnstrm survey & - & $07 / 09 / 12$ & 9.95 & 4.00 \\
\hline Martis Creek at Hwy 267 & - & 07/09/12 & 7.33 & 3.71 \\
\hline M. Martis Cr. Near Confl. & - & 07/09/12 & 3.72 & 3.26 \\
\hline Martis Cr. Upstrm confluence & - & $07 / 09 / 12$ & 3.50 & 3.98 \\
\hline Martis Lk In dwnstrm surv, & - & $07 / 09 / 12$ & 4.79 & 4.19 \\
\hline Martis Lk In dwnstrm surv. & - & $07 / 09 / 12$ & 6.44 & 4.46 \\
\hline Martis Lk In dwnstrm surv. & - & $07 / 09 / 12$ & 4.25 & 4.19 \\
\hline Martis Lake Inlet & - & $07 / 09 / 12$ & 8.22 & 4.78 \\
\hline Martis Lake Inlet upstrm & - & $07 / 09 / 12$ & 1.70 & 3.89 \\
\hline Donner Creek & - & $07 / 09 / 12$ & 4.36 & 4.30 \\
\hline Truckee R. @ Donner Cr. & - & $07 / 09 / 12$ & 2.73 & 4.09 \\
\hline Truckee R. @ Donner Cr. & - & $07 / 09 / 12$ & 2.08 & 4.03 \\
\hline Jake's Bridge & - & 08/02/12 & 0.604 & 2.10 \\
\hline Upstream survey 1 & - & 08/02/12 & 0.814 & 2.16 \\
\hline Pappe's Bridge & - & $08 / 02 / 12$ & 34.4 & 5.53 \\
\hline Upstream survey 2 & - & $08 / 02 / 12$ & 41.4 & 6.04 \\
\hline Upstream survey 3 & - & $08 / 02 / 12$ & 47.1 & 6.43 \\
\hline Upstream survey 4 & - & $08 / 02 / 12$ & 54.8 & 6.93 \\
\hline Upstream survey 5 & - & $08 / 02 / 12$ & 46.0 & 6.44 \\
\hline Upstream survey 6 & - & $08 / 02 / 12$ & 70.5 & 7.87 \\
\hline Upstream survey 7 & - & $08 / 02 / 12$ & 65.2 & 7.63 \\
\hline Upstream survey 8 & - & $08 / 02 / 12$ & 74.8 & 8.18 \\
\hline Upstream survey 9 & - & $08 / 02 / 12$ & 75.4 & 8.26 \\
\hline Upstream survey 10 & - & $08 / 02 / 12$ & 80.3 & 8.56 \\
\hline Upstream survey 11 & - & 08/02/12 & 89.2 & 9.04 \\
\hline MC05 & 99 & 08/02/12 & 24.7 & 5.15 \\
\hline Martis Deep Pool & - & $08 / 02 / 12$ & 10.9 & 3.86 \\
\hline Martis Surv. Dwnstrm & - & $08 / 02 / 12$ & 7.29 & 3.44 \\
\hline Martis Cr at Hwy 267 & - & $08 / 02 / 12$ & 6.58 & 3.35 \\
\hline Martis Cr at Hwy 267 & - & $08 / 02 / 12$ & 6.18 & 3.32 \\
\hline Martis $\mathrm{Cr}$ at Hwy 267 & - & 08/02/12 & 5.76 & 3.29 \\
\hline Middle Martis Creek & - & $08 / 02 / 12$ & 66.2 & 8.13 \\
\hline East Martis Cr. & - & $10 / 29 / 12$ & 6.79 & 3.75 \\
\hline MC-02 & - & $3 / 29 / 13$ & 11.5 & 8.75 \\
\hline MC-04 & -50 & $3 / 29 / 13$ & 19.0 & 9.87 \\
\hline
\end{tabular}


Table A2. Cont.

\begin{tabular}{ccccc}
\hline Sample ID & $\begin{array}{c}\text { Survey Distance }{ }^{\mathbf{1 , 2}} \text { from } \\
\text { Xe Injection Point } \mathbf{( m )}\end{array}$ & $\begin{array}{c}\text { Collection } \\
\text { Date }\end{array}$ & $\begin{array}{c}\text { Act } \\
\text { (pCi/L) }\end{array}$ & $\begin{array}{c}\text { Error 95\% } \\
\text { CI }\end{array}$ \\
\hline MC-09 & -170 & $3 / 29 / 13$ & 31.1 & 11.5 \\
MC-10 & -182 & $3 / 29 / 13$ & 29.8 & 11.4 \\
MC-13 & -269 & $3 / 29 / 13$ & 24.0 & 10.7 \\
MC-17 & -415 & $3 / 29 / 13$ & 30.3 & 11.6 \\
MC01 & 35 & $4 / 29 / 13$ & 49.6 & 9.74 \\
Surv. 1 (upstrm of MC34) & - & $4 / 29 / 13$ & 4.48 & 4.67 \\
MC02 & 49 & $4 / 29 / 13$ & 60.7 & 10.7 \\
Surv. 2 (upstrm of MC34) & - & $4 / 29 / 13$ & 2.38 & 4.35 \\
Surv. 3 (upstrm of MC34) & - & $4 / 29 / 13$ & 9.83 & 5.61 \\
MC34 & 965 & $4 / 29 / 13$ & 85.7 & 12.5 \\
MC-04 & -50 & $4 / 29 / 13$ & 65.3 & 11.2 \\
Golf Pass Br. upstrm of August & - & $4 / 29 / 13$ & 2.46 & 4.50 \\
survey & - & $4 / 29 / 13$ & 2.48 & 4.54 \\
Large Golf Br. upstrm of August & - & $4 / 29 / 13$ & 17.4 & 6.77 \\
survey & 128 & $4 / 29 / 13$ & 19.3 & 7.03 \\
MC08 & 99 & $4 / 29 / 13$ & 79.5 & 12.5 \\
MC05 & 56 & &
\end{tabular}

Notes: ${ }^{1}$ Negative distances are upstream and positive distances are downstream from the Xe introduction point (MC00). ${ }^{2}$ Two dashes (-) denote no distance recorded.

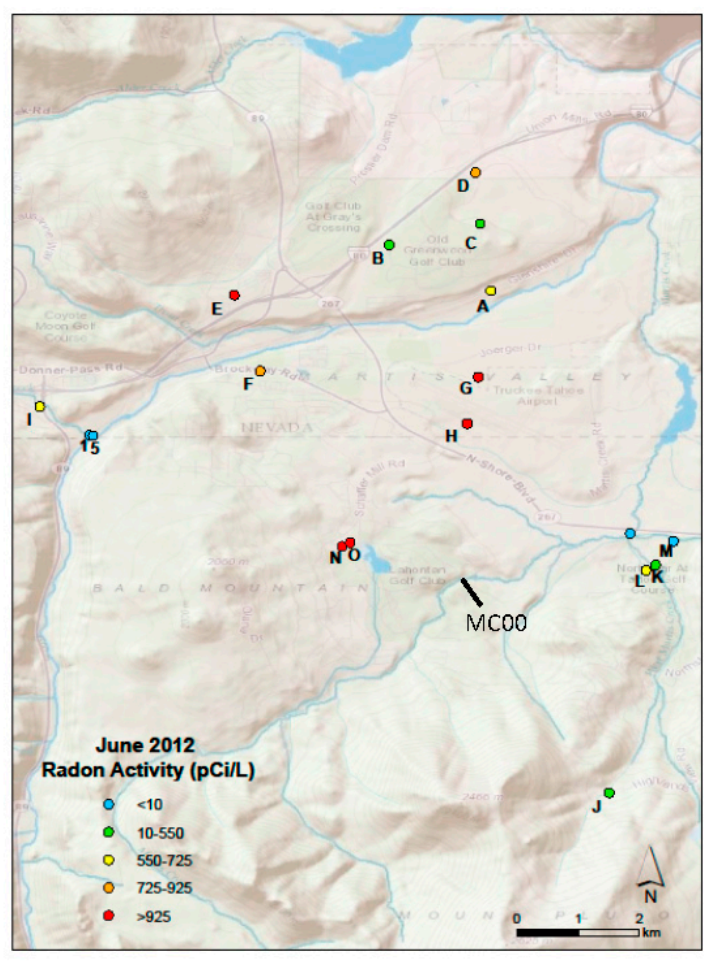

(a)

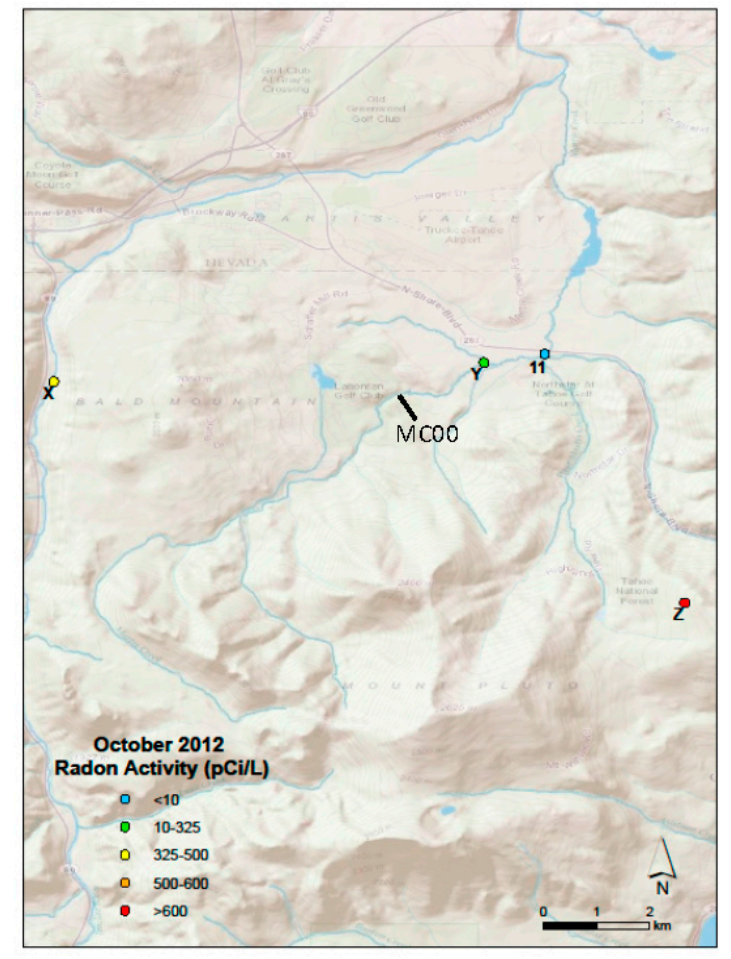

(b)

Figure A1. (a) Well locations noted in Table A1; (b) Spring locations noted in Table A1. 


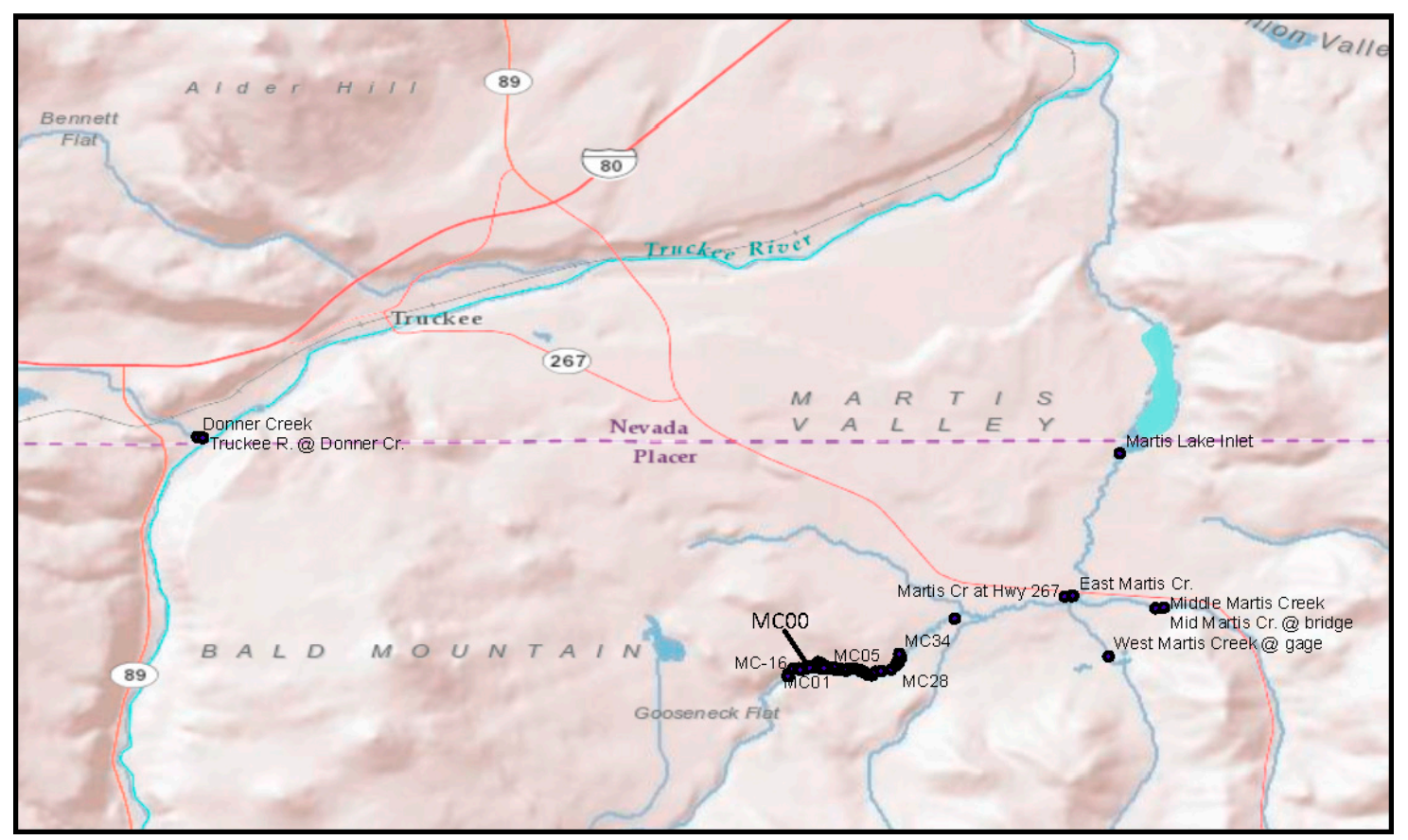

Figure A2. Surface water locations noted in Table A2.

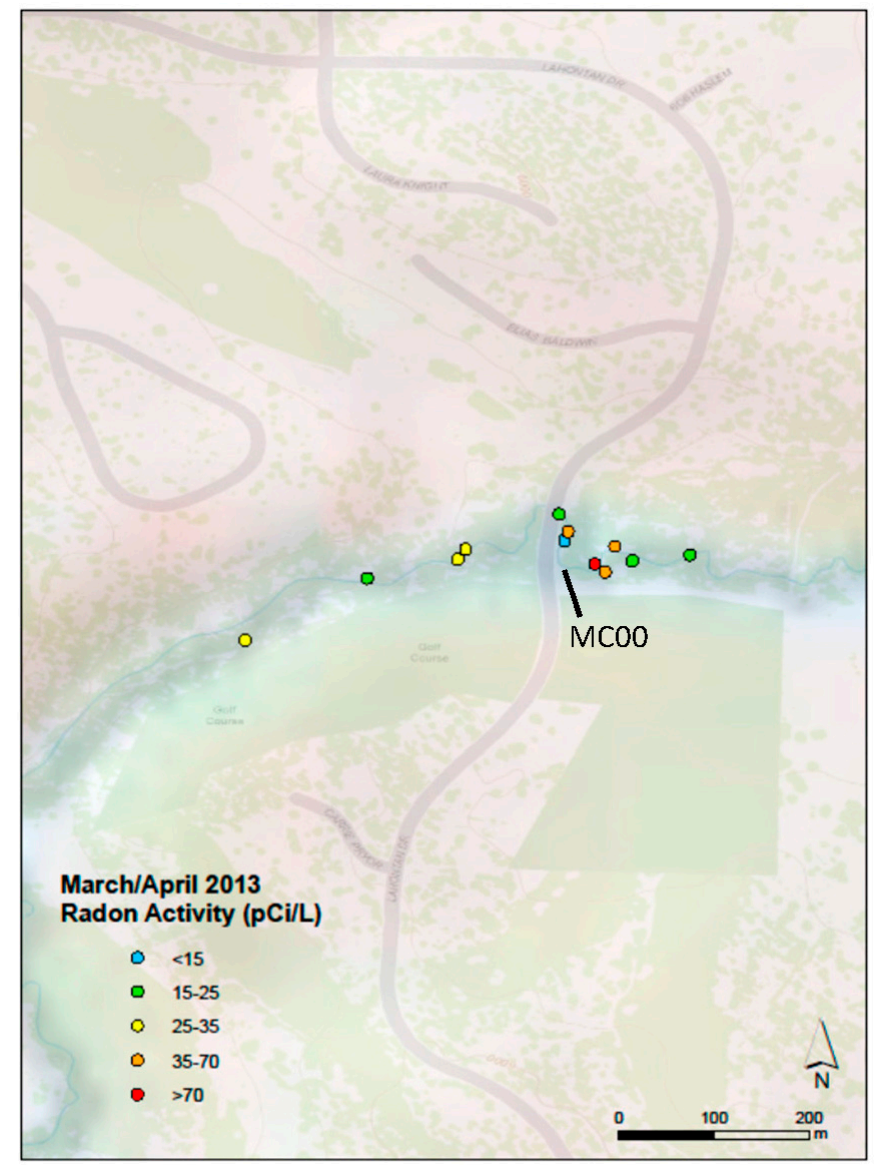

Figure A3. Results of March/April 2013 Radon survey, also shown in Table A2. 


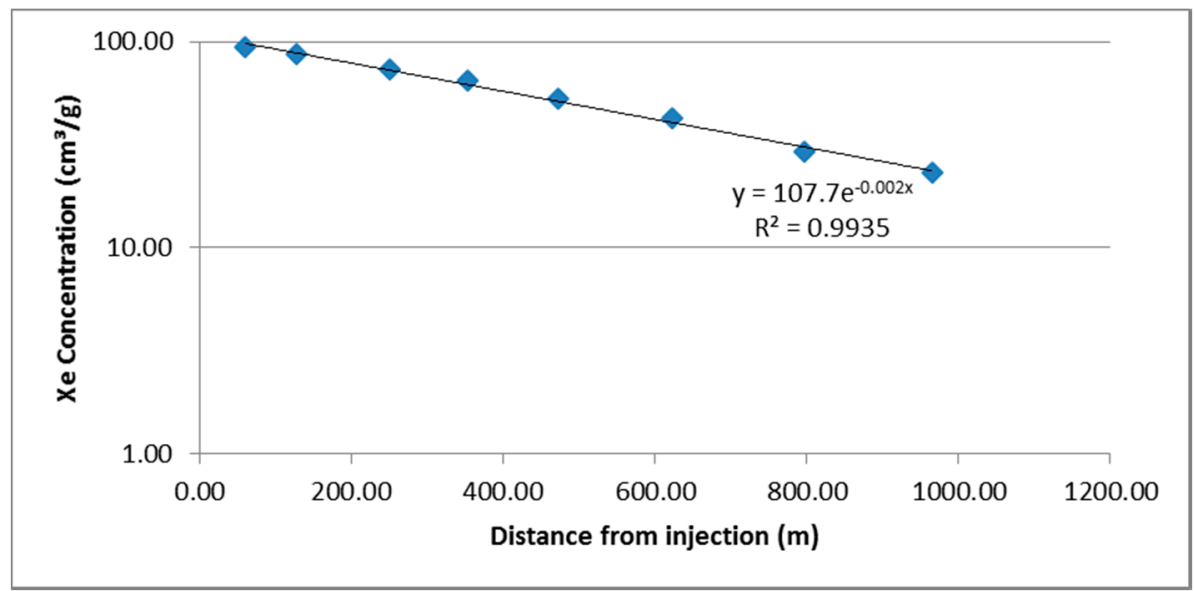

Figure A4. Exponential decrease in the tracer concentrations shown on a plot of log Xe concentration vs distance from $\mathrm{Xe}$ tracer injection location.

Table A3. Measured ${ }^{222} \mathrm{Rn}$ activity levels for surface water samples in the Martis Valley region (other than those shown in Table 1) corresponding to locations on Figures 1 and A2.

\begin{tabular}{|c|c|c|c|}
\hline Sample ID & Collection Date & Act $(\mathrm{pCi} / \mathrm{L})$ & Error $95 \% \mathrm{CI}$ \\
\hline West Martis Creek @ USGS gage & $12 / 19 / 11$ & 4.05 & 1.90 \\
\hline Truckee River @ Donner Creek & $12 / 20 / 11$ & 12.6 & 12.3 \\
\hline Martis Creek @ \#3 Bridge & $12 / 20 / 11$ & 57.5 & 36.3 \\
\hline Martis Creek at Hwy 267 & $12 / 20 / 11$ & 11.5 & 3.81 \\
\hline Donner Creek (between Truckee River and West River Rd) & $06 / 21 / 12$ & 2.17 & 2.94 \\
\hline Truckee River (40 m downstream of Donner Cr. confl.) & $06 / 21 / 12$ & 2.43 & 3.00 \\
\hline Mid Martis Cr. @ bridge & $07 / 09 / 12$ & 91.9 & 8.62 \\
\hline Martis Cr. Dwnstrm survey & $07 / 09 / 12$ & 8.92 & 3.41 \\
\hline Martis Cr. Upstream survey & $07 / 09 / 12$ & 14.9 & 4.50 \\
\hline Martis Creek at Hwy 267 & $07 / 09 / 12$ & 7.33 & 3.71 \\
\hline Martis Cr. Upstrm confluence & $07 / 09 / 12$ & 3.50 & 3.98 \\
\hline Martis Lake Inlet & $07 / 09 / 12$ & 8.22 & 4.78 \\
\hline Donner Creek & $07 / 09 / 12$ & 4.36 & 4.30 \\
\hline Truckee R. @ Donner Cr. & $07 / 09 / 12$ & 2.73 & 4.09 \\
\hline Truckee R. @ Donner Cr. & $07 / 09 / 12$ & 2.08 & 4.03 \\
\hline Martis Creek at Hwy 267 & $08 / 02 / 12$ & 6.58 & 3.35 \\
\hline Martis Creek at Hwy 267 & $08 / 02 / 12$ & 6.18 & 3.32 \\
\hline Martis Creek at Hwy 267 & $08 / 02 / 12$ & 5.76 & 3.29 \\
\hline Middle Martis Creek & $08 / 02 / 12$ & 66.2 & 8.13 \\
\hline East Martis Creek & $10 / 29 / 12$ & 6.79 & 3.75 \\
\hline
\end{tabular}

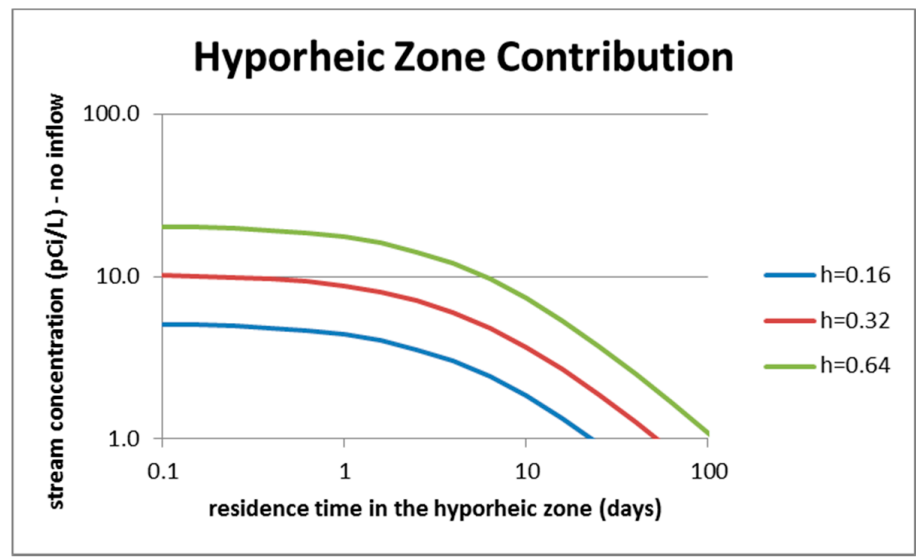

Figure A5. Contribution of hyporheic zone exchange to the stream water ${ }^{222} \mathrm{Rn}$ concentration, depending on residence time in the hyporheic zone, for different values of hyporheic zone thickness $h$. 


\section{References}

1. Brown and Caldwell. Martis Valley Groundwater Management Plan. Available online: http://www. northstarcsd.com/docs/Water/MartisValleyGMPFinal4-18-13.pdf (accessed on 25 October 2017).

2. Meixner, T.; Manning, A.H.; Stonestrom, D.A.; Allen, D.M.; Ajami, H.; Blasch, K.W.; Brookfield, A.E.; Castro, C.L.; Clark, J.F.; Gochis, D.J.; et al. Implications of projected climate change for groundwater recharge in the western United States. J. Hydrol. 2016, 534, 124-138. [CrossRef]

3. Dettinger, M.D.; Cayan, D.R. Large-scale atmospheric forcing of recent trends toward early snowmelt runoff in California. J. Clim. 1995, 8, 606-623. [CrossRef]

4. Dettinger, M.D.; Cayan, D.R.; Meyer, M.K.; Jeton, A.E. Simulated hydrologic responses to climate variations and change in the Merced, Carson, and American River Basins, Sierra Nevada, California, 1900-2099. Clim. Chang. 2004, 62, 283-317. [CrossRef]

5. Huntington, J.L.; Niswonger, R.G. Role of surface-water and groundwater interactions on projected summertime streamflow in snow dominated regions: An integrated modeling approach. Water Resour. Res. 2012, 48, W11524. [CrossRef]

6. Roy, J.W.; Zaitlin, B.; Hayashi, M.; Watson, S.B. Influence of groundwater spring discharge on small-scale spatial variation of an alpine stream ecosystem. Ecohydrology 2011, 4, 661-670. [CrossRef]

7. Hunt, R.J.; Strand, M.; Walker, J.F. Measuring groundwater-surface water interaction and its effect on wetland stream benthic productivity, Trout Lake watershed, northern Wisconsin, USA. J. Hydrol. 2006, 320, 370-384. [CrossRef]

8. Gorelick, S.M.; Zheng, C. Global change and the groundwater management challenge. Water Resour. Res. 2015, 51, 3031-3051. [CrossRef]

9. Barlow, P.M.; Leake, S.A. Streamflow Depletion by Wells-Understanding and Managing the Effects of Groundwater Pumping on Streamflow. USGS Circular 1376. 2012. Available online: https:/ / pubs.usgs.gov/ circ/1376/pdf/circ1376_barlow_report_508.pdf (accessed on 25 October 2017).

10. Essaid, H.I.; Caldwell, R.R. Evaluating the impact of irrigation on surface water-Groundwater interaction and stream temperature in an agricultural watershed. Sci. Total Environ. 2017, 599-600, 581-596. [CrossRef] [PubMed]

11. State of California, Sustainable Groundwater Management Act. 2014. Available online: http:/ / opr.ca.gov/ docs/2014_Sustainable_Groundwater_Management_Legislation_092914.pdf (accessed on 11 October 2017).

12. Mullinger, N.J.; Binley, A.M.; Pates, J.M.; Crook, N.P. Radon in Chalk streams: Spatial and temporal variation of groundwater sources in the Pang and Lambourn catchments, UK. J. Hydrol. 2007, 339, 172-182. [CrossRef]

13. Burnett, W.C.; Peterson, R.N.; Santos, I.R.; Hicks, R.W. Use of automated radon measurements for rapid assessment of groundwater flow into Florida streams. J. Hydrol. 2010, 380, 298-304. [CrossRef]

14. Unland, N.P.; Cartwright, I.; Andersen, M.S.; Rau, G.C.; Reed, J.; Gilfedder, B.S.; Atkinson, A.P.; Hofmann, H. Investigating the spatio-temporal variability in groundwater and surface water interactions: A multi-technique approach. Hydrol. Earth Syst. Sci. 2013, 17, 3437-3453. [CrossRef]

15. Kalbus, E.; Reinstorf, F.; Schirmer, M. Measuring methods for groundwater-Surface water interactions: A review. Hydrol. Earth Syst. Sci. 2006, 10, 873-887. [CrossRef]

16. McCallum, J.L.; Cook, P.G.; Berhane, D.; Rumpf, C.; McMahon, G. Quantifying groundwater flows to streams using differential flow gaugings and water chemistry. J. Hydrol. 2012, 416 (Suppl. C), 118-132. [CrossRef]

17. Xie, Y.; Cook, P.G.; Shanafield, M.; Simmons, C.T.; Zheng, C. Uncertainty of natural tracer methods for quantifying river-aquifer interaction in a large river. J. Hydrol. 2016, 535 (Suppl. C), 135-147. [CrossRef]

18. Bertrand, G.; Siergieiev, D.; Ala-Aho, P.; Pekka, R. Environmental tracers and indicators bringing together groundwater, surface water and groundwater-dependent ecosystems: Importance of scale in choosing relevant tools. Environ. Earth Sci. 2014, 72, 813-827. [CrossRef]

19. Gilfedder, B.S.; Frei, S.; Hofmann, H.; Cartwright, I. Groundwater discharge to wetlands driven by storm and flood events: Quantification using continuous Radon-222 and electrical conductivity measurements and dynamic mass-balance modelling. Geochim. Cosmochim. Acta 2015, 165, 161-177. [CrossRef]

20. Harrington, G.A.; Gardner, W.P.; Munday, T.J. Tracking groundwater discharge to a large river using tracers and geophysics. Groundwater 2014, 52, 837-852. [CrossRef] [PubMed]

21. Gardner, W.P.; Harrington, G.A.; Solomon, D.K.; Cook, P.G. Using terrigenic ${ }^{4}$ He to identify and quantify regional groundwater discharge to streams. Water Resour. Res. 2011, 47, W06523. [CrossRef] 
22. Banks, E.W.; Simmons, C.T.; Love, A.J.; Shand, P. Assessing spatial and temporal connectivity between surface water and groundwater in a regional catchment: Implications for regional scale water quantity and quality. J. Hydrol. 2011, 404, 30-49. [CrossRef]

23. Martinez, J.L.; Raiber, M.; Cox, M.E. Assessment of groundwater-surface water interaction using long-term hydrochemical data and isotope hydrology: Headwaters of the Condamine River, Southeast Queensland, Australia. Sci. Total Environ. 2015, 536, 499-516. [CrossRef] [PubMed]

24. Yu, M.C.L.; Cartwright, I.; Braden, J.L.; de Bree, S.T. Examining the spatial and temporal variation of groundwater inflows to a valley-to-floodplain river using ${ }^{222} \mathrm{Rn}$, geochemistry and river discharge: The Ovens River, southeast Australia. Hydrol. Earth Syst. Sci. 2013, 17, 4907-4924. [CrossRef]

25. Chanyotha, S.; Kranrod, C.; Burnett, W.C.; Lane-Smith, D.; Simko, J. Prospecting for groundwater discharge in the canals of Bangkok via natural radon and thoron. J. Hydrol. 2014, 519, 1485-1492. [CrossRef]

26. Genereux, D.P.; Hemond, H.F. Naturally occurring radon 222 as a tracer for streamflow generation: Steady State methodology and field example. Water Resour. Res. 1990, 26, 3065-3075.

27. Cook, P.G.; Lamontagne, S.; Berhane, D.; Clark, J.F. Quantifying groundwater discharge to Cockburn River, southeastern Australia, using dissolved gas tracers ${ }^{222} \mathrm{Rn}$ and $\mathrm{SF}_{6}$. Water Resour. Res. 2006, 42, W10411. [CrossRef]

28. Cook, P.G. Estimating groundwater discharge to rivers from river chemistry surveys. Hydrol. Proc. 2013, 27, 3694-3707. [CrossRef]

29. Cook, P.G.; Love, A.J.; Dighton, J.C. Inferring ground water flow in fractured rock from dissolved radon. Ground Water 1999, 37, 606-610. [CrossRef]

30. Lamontagne, S.; Cook, P.G. Estimation of Hyporheic Exchange in a Subtropical Stream Using Bromide and $\mathrm{SF}_{6}$ Injection and ${ }^{222} \mathrm{Rn}$ Disequilibrium: CSIRO Land and Water Science Report 48/06. 2006. Available online: http:/ / www.clw.csiro.au/publications/science/2006/sr48-06.pdf (accessed on 25 October 2017).

31. Lamontagne, S.; Cook, P.G. Estimation of hyporheic water residence time in situ using ${ }^{222} \mathrm{Rn}$ disequilibrium. Limnol. Oceanogr. Methods 2007, 5, 407-416. [CrossRef]

32. Zane, M. Reaeration of Sagehen Creek Near Truckee, CA. Bachelor's Thesis, University of California, Santa Barbara, CA, USA, 11 June 2010.

33. Cox, C.; Esser, B. Estimating groundwater inflow to Squaw Creek using radon. LLNL Nuclear Science Intern Program. 2009. Unpublished manuscript.

34. Clark, J.F.; Wanninkhof, R.; Schlosser, P.; Simpson, H.J. Gas exchange rates in the tidal Hudson River using a dual tracer technique. Tellus 1994, 46B, 274-285. [CrossRef]

35. Benson, A.; Zane, M.; Becker, T.E.; Visser, A.; Urióstegui, S.H.; DeRubeis, E.; Moran, J.E.; Esser, B.K.; Clark, J.F. Quantifying reaeration rates in alpine streams using deliberate gas tracer experiments. Water 2014, 6, 1013-1027. [CrossRef]

36. California's Groundwater Bulletin 118: North Lahontan Hydrologic Region, Martis Valley Groundwater Basin. Available online: www.water.ca.gov/groundwater/bulletin118/basindescriptions/6-67.pdf (accessed on 5 January 2013).

37. Interflow Hydrology, Inc.; Cordilleran Hydrology, Inc. Measurement of Ground Water Discharge to Streams Tributary to the Truckee River in Martis Valley, Placer and Nevada Counties, California; IFH Report 2003-02; Interflow Hydrology, Inc.: Truckee, CA, USA; Cordilleran Hydrology, Inc.: Reno, NV, USA, 11 April 2003.

38. Shaw, D.; Hastings, B.; Drake, K.; Hogan, M.; Lindstrom, S. Martis Watershed Assesment. 2012. Available online: www.truckeeriverwc.org/images/documents/Martis_Watershed_Assessment_Final_ 041012_compressed.pdf (accessed on 25 October 2017).

39. Cox, C.; Bibby, R.; Esser, B. Radon emanation experiments with Squaw Creek sediments. LLNL Nuclear Science Intern Program. 2009. Unpublished manuscript.

40. Visser, A.; Singleton, M.J.; Hillegonds, D.J.; Velsko, C.A.; Moran, J.E.; Esser, B.K. A membrane inlet mass spectrometry system for noble gases at natural abundances in gas and water samples. Rapid Commun. Mass Spectrom. 2013, 27, 2472-2482. [CrossRef] [PubMed]

41. Shelton, J.L.; Fram, M.S.; Munday, C.M.; Belitz, K. Groundwater-Quality Data for the Sierra Nevada Study Unit, 2008: Results from the California GAMA Program. 2010. Available online: https:/ /www.waterboards. ca.gov / gama/docs/dsr_sierra_regional.pdf (accessed on 25 October 2017).

42. Appleton, J.D. Radon: Sources, health risks, and hazard mapping. Ambio 2007, 36, 85-89. [CrossRef] 
43. Williams, M.R.; Leydecker, A.; Brown, A.D.; Melack, J.M. Processes regulating the solute concentrations of snowmelt runoff in two subalpine catchments of the Sierra Nevada, California. Water Resour. Res. 2001, 37, 1993-2008. [CrossRef]

44. Williams, M.W.; Melack, J.M. Solute chemistry of snowmelt and runoff in an Alpine Basin, Sierra Nevada. Water Resour. Res. 1991, 27, 1575-1588. [CrossRef]

45. Baeza, A.; del Rio, M.; Jimenez, A.; Miro, C.; Paniagua, J. Influence of geology and soil particle size on the surface area/volume activity ratio for natural radionuclides. J. Radioanal. Nucl. Chem. 1995, 189, 289-299. [CrossRef]

46. Schilling, K.E.; Zhang, Y.K.; Drobney, P. Water table fluctuations near an incised stream, Walnut Creek, Iowa. J. Hydrol. 2004, 286, 236-248. [CrossRef]

47. Sappa, G.; Ferranti, F.; De Filippi, F.M.; Cardillo, G. $\mathrm{Mg}^{2+}$ based method for Pertuso Spring discharge evaluation. Water 2017, 9, 67. [CrossRef]

48. Bourke, S.A.; Harrington, G.; Cook, P.; Post, V.; Dogramaci, S. Carbon-14 in streams as a tracer of discharging groundwater. J. Hydrol. 2014, 519, 117-130. [CrossRef]

49. Kim, H.; Lee, K.-K.; Lee, J.-Y. Numerical verification of hyporheic zone depth estimation using streambed temperature. J. Hydrol. 2014, 511 (Suppl. C), 861-869. [CrossRef]

50. Cranswick, R.H.; Cook, P.G.; Lamontagne, S. Hyporheic zone exchange fluxes and residence times inferred from riverbed temperature and radon data. J. Hydrol. 2014, 519, 1870-1881. [CrossRef]

(c) 2018 by the authors. Licensee MDPI, Basel, Switzerland. This article is an open access article distributed under the terms and conditions of the Creative Commons Attribution (CC BY) license (http://creativecommons.org/licenses/by/4.0/). 